\title{
1 Petrogenesis and structure of oceanic crust in the Lau back-arc basin
}

4 Deborah E. Eason* and Robert A. Dunn

* Corresponding author

7 Department of Geology and Geophysics, 1680 East-West Road, University of Hawaii, Honolulu,

8 HI 96822, USA (phone: 808-956-6105; fax: 808-956-5154; email: deborahe@hawaii.edu)

11 Keywords: back-arc spreading centers; Lau back-arc basin; Valu Fa Ridge; oceanic crust;

12 magma differentiation

\section{Abstract}

16 Oceanic crust formed along spreading centers in the Lau back-arc basin exhibits a

17 dramatic change in structure and composition with proximity to the nearby Tofua Arc. Results

18 from recent seismic studies in the basin indicate that crust formed near the Tofua Arc is

19 abnormally thick $(8-9 \mathrm{~km})$ and compositionally stratified, with a thick low-velocity (3.4-4.5

$20 \mathrm{~km} / \mathrm{s}$ ) upper crust and an abnormally high-velocity $(7.2-7.4+\mathrm{km} / \mathrm{s}$ ) lower crust (Arai and Dunn,

21 2014). Lava samples from this area show arc-like compositional enrichments and tend to be

22 more vesicular and differentiated than typical mid-ocean ridge basalts, with an average $\mathrm{MgO}$ of

$23 \sim 3.8$ wt. \%. We propose that slab-derived water entrained in the near-arc ridge system not only 
24 enhances mantle melting, as commonly proposed to explain high crustal production in back-arc

25 environments, but also affects magmatic differentiation and crustal accretion processes. We

26 present a petrologic model of Lau back-arc crustal formation that successfully predicts the

27 unusual crustal stratification imaged in the near-arc regions of the Lau basin, as well as the

28 highly fractionated basaltic andesites and andesites that erupt there. Results from phase

29 equilibria modeling using MELTS indicate that the high water contents found in near-arc

30 parental melts can lead to crystallization of an unusually mafic, high velocity cumulate layer.

31 Best-fit model runs contain initial water contents of $\sim 0.5-1.0 \mathrm{wt} . \% \mathrm{H}_{2} \mathrm{O}$ in the parental melts,

32 and successfully reproduce geochemical trends of the erupted lavas while crystallizing a

33 cumulate assemblage with calculated seismic velocities consistent with those observed in the

34 near-arc lower crust. Modeled residual melts are also lower density than their dry equivalents,

35 which aids in melt segregation from the cumulate layer. Low-density, water-rich residual melts

36 can lead to the eruption of vesicular lavas that are unusually evolved for an oceanic spreading

37 center.

$39 \quad 1.0$ Introduction

Back-arc basins are productive centers of crustal formation that generate extensive

41 regions of oceanic crust through rifting and organized spreading. Because their mantle melting

42 regions are influenced by mantle flow, thermal structure, and chemistry above a subducting

43 lithospheric slab, back-arc spreading centers host a diversity of crustal structure, composition,

44 and processes not typically found at mid-ocean ridges. Numerous petrological and geophysical

45 studies along back-arc spreading centers have shown changes in melt production and lava

46 chemistry that correlate with proximity to the active arc (e.g., Stolper and Newman, 1994; 
47 Martinez and Taylor, 2002; Langmuir et al., 2006). Current models and observations suggest

48 that back-arc spreading centers located close to an active arc entrain water (and other related

49 components) released from the dehydrating, subducting slab, which enhances mantle melting

50 beneath the spreading centers (e.g., Kelley et al., 2006). This leads to a higher melt flux to the

51 ridge and erupted lavas that are more arc-like in composition than typical mid-ocean ridge

52 basalts (MORB).

53 While increases in melt production and crustal thickness in back-arc settings are often

54 ascribed to high water contents, recent evidence in the Lau back-arc basin points to associated

55 differences in crustal structure as well (Peirce et al., 2001). The L-SCAN active source seismic

56 tomography experiment along the Eastern Lau Spreading Center identified large regions of an

57 anomalously thick crust with an unusual vertical stratification formed at back-arc spreading

58 centers located close to the active Tofua arc (Dunn and Martinez, 2011; Arai and Dunn, 2014).

59 This near-arc crust has a thick upper layer of unusually low seismic velocities and a lower layer

60 of very high seismic velocities $(7.2-7.4+\mathrm{km} / \mathrm{s})$ just above the base of the crust. The lavas that

61 form the volcanic layer of this crust are both more vesicular (e.g., Pearce et al., 1994) and more

62 differentiated than is typical of mid-ocean ridge basalts (e.g., Pearce et al., 2005; Escrig et al.,

63 2009), with an average of $\sim 3.8$ wt. $\% \mathrm{MgO}$, and carry trace element and isotope signatures

64 derived from the nearby subducting slab (e.g., Escrig et al., 2009; Bézos et al., 2009). In

65 contrast, spreading centers located farther from the arc form crust with a more normal

66 geophysical structure for their spreading rate, and primarily erupt basalts. The transition

67 between these two types of crust occurs over just a few kilometers, and closely correlates with

68 major changes in bathymetric depth and morphology, Bouguer gravity, and the depth to the top

69 of the sub-ridge magmatic system (e.g., Dunn and Martinez, 2011; Dunn et al., 2013). 
The process that generates this unusual crustal stratification is currently unknown.

71 Similar high velocity lower crusts have been reported in other back-arc regions, including the

72 Yamato Basin in the Japan Sea (Sato et al., 2014; Hirahara et al., 2015), the Izu-Bonin-Mariana

73 Arc (Kodaira et al., 2007; Takahashi et al., 2008, 2009), and the Aleutian arc (e.g., Shillington et

74 al., 2004; Behn and Kelemen, 2006), as well as rifted continental margins (Korenaga et al.,

75 2000). Sato et al. (2014) propose that the anomalous back-arc crust in the Japan Sea is the result

76 of higher mantle potential temperature (e.g., Kelemen and Holbrook, 1995; Korenaga et al.,

77 2002). However, this is likely not the underlying mechanism in the Lau basin, where mantle

78 potential temperature is thought to be hottest in the northern areas of the basin, decreasing to the

79 south where the anomalous crust is actually observed (Kelley et al., 2006; Wiens et al., 2006;

80 Wei et al., 2015).

81 To explain the stratified, anomalous crust, Arai and Dunn (2014) instead proposed that

82 entrainment of slab-derived water in mantle melts alters crystallizing phase proportions by

83 suppressing plagioclase relative to olivine and clinopyroxene, leading to crystallization of a

84 dense layer of mafic-to-ultramafic cumulates at the bottom of the crust and a thick, more silica-

85 rich upper crust (Fig. 1). While this process was not modeled in their paper, water has long been

86 understood to play a major role in the generation, evolution and eruption of magma in subduction

87 zone settings. Slab-derived water lowers the mantle solidus (e.g., Kushiro et al., 1968), driving

88 melt production in the overriding mantle wedge (e.g., Davies and Bickle, 1991; Stolper and

89 Newman, 1994). Water also suppresses mineral liquidus temperatures (e.g., Nicholls and

90 Ringwood, 1973), leading to changes in magma crystallization sequences (e.g., Grove and Baker,

91 1984; Sisson and Grove, 1993), and is associated with production of silica-rich lavas (e.g.,

92 Gaetani et al., 1994). While much attention has been given to water's effects on mantle melting 
93 and eruption processes, some of its effects on crustal differentiation and formation are difficult to

94 constrain due to the complicated magmatic processes typical of arc systems (e.g., crustal

95 assimilation and contamination). Back-arc spreading centers are simpler settings to study the

96 effects of water enrichment on the crustal magmatic system, as they entrain water-rich material

97 from the subducted slab while lacking some of the additional complications found at arcs; crustal

98 assimilation, for example, is likely less than at arcs with their thick sequences of heterogeneous

99 crust.

In this study, we apply thermodynamic models of phase equilibria to the extensive

101 geochemical datasets available along Lau back-arc spreading centers to test the crustal formation

102 hypothesis of Arai and Dunn (2014). We compare predicted magma evolution trends and

103 estimations of crustal seismic properties with available geochemical and geophysical

104 observations to constrain likely formation conditions for this unusual oceanic crust.

105

$106 \quad 1.1$ Setting

107

Opening due to rollback of the Tonga trench (e.g., Hawkins, 1994), the Lau back-arc

108 basin is a wedge-shaped extensional basin located west of the currently active Tofua arc (Fig. 2).

109 Unlike some back-arc extensional settings where broad crustal rifting and subsequent partial

110 melting and modification of pre-existing arc crust has been proposed (e.g., Takahashi et al.,

111 2008), most new crustal formation in the eastern Lau back-arc occurs primarily at well-organized

112 spreading centers. Seismic imaging along these spreading centers indicates a single narrow axial

113 magmatic system (e.g., Jacobs et al., 2007; Dunn et al., 2013), and sonar and magnetic data

114 indicate a narrow and persistent axis of crustal formation for $>2$ Myr (e.g., Sleeper, 2011; Austin, 115 2012; Sleeper and Martinez, 2014). The current spreading configuration in the central Lau basin 
116 initiated in the north and propagated southward along the Central Lau Spreading Center (CLSC),

117 Eastern Lau Spreading Center (ELSC), and Valu Fa Ridge (VFR), resulting in the basin's current

118 wedge shape (Fig. 2) (e.g., Hawkins, 1995; Taylor et al., 1996).

119 The ELSC and VFR, which are the focus of this study, consist of smaller ridge segments

120 divided by second- and third-order discontinuities (ELSC1-4 and VFR1-2; Fig. 3a). These ridge

121 segments range from $\sim 100$ to $40 \mathrm{~km}$ from the active arc, and show variations in crustal thickness

122 and lava compositions consistent with higher contributions from subduction-related melts toward

123 the south (e.g., Langmuir et al., 2006; Martinez et al., 2006; Pearce and Stern, 2006; Escrig et al.,

124 2009). Despite decreasing spreading rates toward the south (from $\sim 96$ to $\sim 40 \mathrm{~mm} / \mathrm{yr}$ ), the

125 shallow, axial high morphology and thick crust in the south indicate higher magma supply close

126 to the active volcanic arc (Figs. 2, 3) (e.g., Martinez and Taylor, 2002; Martinez et al., 2006).

127 The CLSC and northern ELSC segments (ELSC1-2) are currently located far enough from the

128 arc that the arc's influence is greatly reduced, and their magma supply and resulting crustal

129 thickness are comparable to MOR of similar intermediate spreading rates. ELSC3 is

130 characterized by a transition in ridge morphology and axial depth, where the deep ( 2700 $\mathrm{m})$

131 ridge axis in the north shoals abruptly to $\sim 1800-2200 \mathrm{~m}$ in the south (Fig. 3b), roughly coincident

132 with the appearance of the seismically-imaged axial magma chamber (AMC) reflector (Harding

133 et al., 2000; Jacobs et al., 2007).

134 The variation in melt supply and crustal accretion observed along the spreading centers is

135 also recorded in older, off-axis crust. The anomalous near-arc crust and more typical oceanic

136 crust form a broad crustal zoning in the basin, with a remarkably sharp transition between the

137 two (Fig. 2). These regions have therefore been identified as two distinct crustal zones, called

138 Domain II (arc-proximal) and Domain III (arc-distal) respectively (Martinez and Taylor, 2002; 
139 Dunn and Martinez, 2011). Domain II crust forms at spreading centers $<50 \mathrm{~km}$ from the active

140 Tofua arc (Dunn and Martinez, 2011; Arai and Dunn, 2014) and is currently being produced

141 along the VFR. ELSC1 and ELSC2 are currently forming Domain III crust, with the

142 southernmost ELSC (segments ELSC3 and ELSC4) producing a narrow zone of crust that is

143 transitional between Domains II and III (Dunn and Martinez, 2011).

At 8-9 km thick, the near-arc Domain II crust is considerably thicker than typical oceanic 145 crust formed at MOR, which averages 6-7 km globally (e.g., White et al., 1992). Models of

146 mantle melting indicates the thick crust in this region is best explained by high melt productivity

147 due to the presence of water in the mantle wedge (Kelley et al., 2006; Harmon and Blackman,

148 2010). Domain II crust also exhibits anomalously high seismic velocities in the lower crust,

149 averaging 7.2-7.4 km/s with some local regions exceeding $7.5 \mathrm{~km} / \mathrm{s}$ (Arai and Dunn, 2014).

150 These values are higher than that expected for a gabbroic lower crust, which typically has wave

151 speeds of $\sim 6.8-7.2 \mathrm{~km} / \mathrm{s}$ (e.g., Dunn and Forsyth, 2007). Meanwhile, the low velocity layer that

152 forms the upper crust (seismic layer 2) is abnormally thick (2.9-3.8 km) with unusually low

153 velocities $(3.4-4.5 \mathrm{~km} / \mathrm{s})$ that extend deeper than expected for a typical volcanic (porous) layer

154 alone (Jacobs et al., 2007; Arai and Dunn, 2014). These observations can be explained by the

155 presence of more evolved rock compositions and higher porosities in the upper crust than typical

156 for crust produced at mid-ocean ridges (Jacobs et al., 2007; Arai and Dunn, 2014).

157 Lava samples from the present Domain II ridge axis (VFR) and the transitional zone are

158 more evolved than typical MORB (Fig. 3c), with abundant basaltic andesites, andesites and a

159 few dacites sampled on the VFR close to the arc (e.g., Pearce et al., 1994; Langmuir et al., 2006).

160 Domain II lavas also show strong enrichments in subduction-related components relative to

161 normal MORB (or the more MORB-like Domain III lavas erupted further to the north), including 
162 enrichments in fluid mobile elements and related ratios (e.g., Ba/Th, Fig. 3d) as well as

163 enrichments associated with a sedimentary contribution (e.g., Th/La, Fig. 3e, and La/Sm,

$164{ }^{206} \mathrm{~Pb} /{ }^{204} \mathrm{~Pb}$, not shown) (Escrig et al., 2009). Samples tend to be highly vesicular (Pearce et al.,

165 1994), and available analyses of water contents, and/or proxy estimates, from the VFR and near-

166 axis seamounts have values as high as $1-5$ wt. $\% \mathrm{H}_{2} \mathrm{O}$ (e.g., Michael et al., 2011).

167 Oceanic crust formed farther north along the ELSC and away from the arc ( $>70 \mathrm{~km}$;

168 Domain III) is similar in structure and composition to global averages for its spreading rate. Its

169 thickness and seismic velocities are consistent with intermediate-rate oceanic crust (Dunn and

170 Martinez, 2011; Dunn et al., 2013). Lavas are primarily back-arc basin basalts (BABB) that have

171 undergone low-to-moderate amounts of crystallization $(\sim 6-8+$ wt.\% MgO), with low enrichments

172 in components typically ascribed to derivation from the slab (Fig. 3), consistent with the

173 interpretation that the ridge has moved too far away from the subducting slab to entrain very

174 much subduction-related material into the melting region (e.g., Hawkins, 1995; Pearce, 1994;

175 Peate et al., 2001; Kent et al., 2002).

176

$177 \quad 2.0$ Data and Methods

178 The along-axis variations of the ELSC and VFR and the window they provide into arc

179 and back-arc melting processes has made them the subject of numerous sampling expeditions

180 and geochemical studies, resulting in an extensive compositional dataset from which to examine

181 crustal formation processes. The major element compositional data used in this study come from

182 the compilation of Gale et al. (2013), which released new sample analyses in addition to

183 providing a cleaned compilation of all the published data available in PetDB

184 (www.earthchem.org/petdb; Lehnert et al., 2000) for the ELSC and VFR (complete references in 
185 Supplementary Material). We primarily use major element compositions for the thermodynamic 186 modeling, but rely on additional trace element compositional data to evaluate consistency and 187 check for indicators of other processes (e.g., crustal assimilation, contamination, or magma 188 mixing) that might affect the samples' geochemical compositions. We have chosen a representative subset from these available data for forward modeling.

190 To limit the effects of other process variations, we have excluded off-axis samples, which may be 191 significantly older or have erupted off-axis. We also exclude samples from overlapping 192 spreading centers (OSCs) and segment ends, which show clear excursions from the general 193 along-axis trends in the Lau data (Fig. 3) (e.g., Escrig et al., 2009). Because they show clear 194 deviations from ridge segment centers, we model these samples separately (see the Discussion 195 section for further analysis of these samples, with full results available in the Supplementary 196 Material). The exclusion of OSC samples also removes the outlier E-MORB sample DR41-1, 197 identified by Escrig et al. (2009) as having isotopic and trace element enrichments similar to 198 Samoan lavas. For the purposes of modeling crystallization trends, we also exclude the few 199 samples with $\mathrm{MgO}<3.0$ wt. \%, where data are sparse and forward models are known to be less 200 reliable.

$201 \quad$ Forward modeling of fractional crystallization was done using alphaMELTS 202 (Antoshechkina and Asimow, 2010), the latest release of the MELTS algorithms for 203 thermodynamic modeling of phase equilibria in magmatic systems (Ghiorso and Sack, 1995; 204 Asimow and Ghiorso, 1998; Smith and Asimow, 2005). Major element composition modeling 205 include $\mathrm{SiO}_{2}, \mathrm{TiO}_{2}, \mathrm{Al}_{2} \mathrm{O}_{3}, \mathrm{FeO} *, \mathrm{MgO}, \mathrm{CaO}, \mathrm{Na}_{2} \mathrm{O}, \mathrm{K}_{2} \mathrm{O}, \mathrm{P}_{2} \mathrm{O}_{5}$, and $\mathrm{H}_{2} \mathrm{O}$. Model runs are 206 isobaric and fractional, with an oxygen fugacity of FMQ-2, which commonly shows good 207 matches to mid-ocean ridge basalt data. We also tested more oxidizing conditions, as might be 
expected in more hydrous environments, but found these model runs consistently produced

209 worse fits to the observed trends. We simulate pressures $(\mathrm{P})$ ranging from $0.05 \mathrm{GPa}-0.22 \mathrm{GPa}$ to

210 approximate conditions from the shallow crustal melt lens down to the Domain II lower crust.

211 We tested multiple starting compositions $\left(\mathrm{C}_{0}\right)$ (see Supplementary Material), fixing

212 relative abundances of all oxides except initial water composition $\left(\mathrm{H}_{2} \mathrm{O}_{i}\right)$, which is allowed to

213 vary. Model results end up being relatively insensitive to reasonable variations in starting

214 composition, so we present results for a single starting composition (MOD3) for the remainder of

215 this paper. We tested variable water contents ranging from 0 to $3.0 \mathrm{wt} . \% \mathrm{H}_{2} \mathrm{O}_{i}$, renormalizing

216 oxide concentrations accordingly so they still total $100 \%$.

217 Model outputs from alphaMELTS (referred to simply as MELTS below) crystallization

218 runs include predictions for the abundance and composition of liquid and solid phases as a

219 function of temperature, and we compare modeled liquid compositional trends against analyzed

220 glass compositions at the scale of individual ridge segments. We also use the calculated mineral

221 compositions and their proportions to estimate the mode and composition of the earliest

222 crystallizing phases. Assuming the lower crust is composed primarily of the early products of

223 fractional crystallization, we use modeled solid assemblages to calculate estimated seismic wave

224 speeds of the lower crust for comparison with results from seismic tomography (Hacker et al.,

225 2003; Hacker and Abers, 2004). We calculate the proportion of each mineral phase (olivine,

226 clinopyroxene, plagioclase) predicted to have fractionated by MELTS for a given solid fraction.

227 Since the physical properties of a mineral are also dependent on its composition, we use the

228 predicted mineral compositions of these fractionated phases to cast each mineral into proportions

229 of appropriate end-members for which physical property data are available: forsterite and fayalite

230 (olivine); anorthite and albite (plagioclase); diopside, hedenbergite and jadeite (clinopyroxene). 
231 We then calculate wave speeds (Hacker and Abers, 2004) for the bulk crystal assemblages at

232 conditions appropriate to off-axis lower crust $\left(0.22 \mathrm{GPa}, 800^{\circ} \mathrm{C}\right)$. Although differences in lower

233 crustal pressure accompany differences in crustal thickness across the study area, the predicted

234 difference in seismic velocities due to this effect are $<0.1 \mathrm{~km} / \mathrm{s}$ and smaller than the resolution of

235 the seismic tomography, and are therefore neglected from further consideration.

\subsection{Results}

Predicted liquid compositions for example model runs are shown in Figure 4 with the modeled dataset shown for comparison (see Supplemental Material Fig. S1 for results from

240 additional oxides). Data from ELSC1 and ELSC2 (red and orange symbols in Fig. 4) lie along a

241 visibly distinct trend from ridge segments to the south (ELSC3-VFR) in $\mathrm{Al}_{2} \mathrm{O}_{3}, \mathrm{FeO}, \mathrm{TiO}_{2}, \mathrm{Na}_{2} \mathrm{O}$,

242 and to a lesser degree $\mathrm{CaO}$ and $\mathrm{K}_{2} \mathrm{O}$ vs. $\mathrm{MgO}$. For $\mathrm{Al}_{2} \mathrm{O}_{3}, \mathrm{FeO}^{*}, \mathrm{TiO}_{2}$, and $\mathrm{Na}_{2} \mathrm{O}$, this offset is

243 consistent with a delay in plagioclase crystallization. Plagioclase crystallization produces a clear

244 kink in these oxide trends, so its appearance in the crystallizing assemblage is easy to detect in

245 lava compositional trends. MELTS runs with higher water contents show a delay in the onset of

246 plagioclase crystallization (Figs. 4, 5), preferentially crystallizing olivine and clinopyroxene

247 initially (Fig. 5), leading to higher $\mathrm{Al}_{2} \mathrm{O}_{3}$ contents and lower $\mathrm{FeO}^{*}, \mathrm{TiO}_{2}$ and $\mathrm{Na}_{2} \mathrm{O}$ contents for a

248 given $\mathrm{MgO}$ (e.g., Sinton and Fryer, 1987). A few oxides exhibit relatively poor fits to the data

249 for all model runs: $\mathrm{SiO}_{2}, \mathrm{CaO}$, and $\mathrm{K}_{2} \mathrm{O}$ show steeper slopes in the data than predicted by

250 MELTS for all $\mathrm{P}$ and $\mathrm{H}_{2} \mathrm{O}_{i}$. Model fits are generally worse at low $\mathrm{MgO}$ contents, as systematic

251 differences between the model and the data accumulate with each temperature step. We also note 252 that inflections in $\mathrm{FeO}^{*}, \mathrm{TiO}_{2}$, and $\mathrm{SiO}_{2}$ vs. $\mathrm{MgO}$ trends at $\sim 4.0$ wt. $\% \mathrm{MgO}$ indicate the onset of 
253 crystallization of an Fe-Ti oxide phase, which does not appear in MELTS runs until below 3.0

254 wt. \% $\mathrm{MgO}$ due to the low fO2 used in the modeling.

255 Major oxide trends from the northern ridge segments ELSC1 and ELSC2, currently

256 producing Domain III type crust at the ridge axis, are best matched by MELTS runs with low

257 water contents ( $<0.5$ wt. \%) (Fig. 4). Ridge segments in both Domain II (VFR) and the

258 transitional region (ELSC3 and ELSC4) are best matched by MELTS runs with higher water

259 contents ( $\sim 0.5-1.0$ wt. \%) at low to moderate pressures (Fig. 4). All data are better matched for

260 model runs with low to moderate pressures $(\sim 1.0-1.5 \mathrm{~kb})$, but overall the data fits are not very

261 sensitive to pressure. The best-fit run varies slightly depending on the oxide- $\mathrm{MgO}$ pairing, but

262 the most water-sensitive oxide trends $\left(\mathrm{Al}_{2} \mathrm{O}_{3}, \mathrm{FeO}^{*}, \mathrm{TiO}_{2}, \mathrm{P}_{2} \mathrm{O}_{5}\right)$ are consistently fit best by a

263 relatively narrow range of model conditions.

264 In order to compare model results across these multiple components, we calculate an

265 overall misfit for each model run and each oxide- $\mathrm{MgO}$ pairing, and then combine these misfits

266 into a total misfit for all oxides of interest (calculation details given in Supplementary Materials).

267 For each model run, we calculate a mean scaled absolute deviation (MSAD) for each oxide-MgO

268 pairing, normalized by the standard error of the data from an idealized fractionation trend for that

269 oxide-MgO pair - see Supplementary Materials for complete details. The resulting mean scaled

270 absolute deviation (MSAD) for a given model run can be thought of as the number of standard

271 errors from the sample trend for any given oxide. This allows us to directly compare model fits

272 across different oxides with different average concentrations and different amounts of scatter,

273 and combine them into a total average MSAD for all oxides for a given set of model conditions.

274 Independent of the starting composition, $\mathrm{SiO}_{2}$ and $\mathrm{K}_{2} \mathrm{O}$ consistently show poor model fits for all 
275 conditions and contribute little to the understanding of this system. We therefore omit them from 276 the total average MSAD.

277 Final calculated total misfits for individual ridge segments are shown in Figure 5. Major 278 oxide trends from the northernmost ridge segment ELSC1, currently producing Domain III type 279 crust at the ridge axis, is best matched by MELTS runs with low water contents ( $\sim 0.2 \mathrm{wt} . \%$

$280 \mathrm{H}_{2} \mathrm{O}_{i}$ ) and low pressures (up to $\sim 1 \mathrm{~kb}$ ) (Fig. 5a). ELSC2, which has recently produced a narrow 281 strip of crust classified as Domain III (Fig. 1), shows more variability and a wider range of 282 model fits, with good fits at $\sim 0.4$ wt. $\% \mathrm{H}_{2} \mathrm{O}_{i}$ at low-to-moderate $\mathrm{P}$, ranging to slightly higher $283 \mathrm{H}_{2} \mathrm{O}_{i}$ at higher P (Fig. 5b). Ridge segments in both Domain II (VFR) and the transitional region 284 (ELSC3 and ELSC4) require MELTS runs with higher water contents at low-to-moderate 285 pressures to match their compositional trends. ELSC3-4 major oxide trends are best matched by 286 MELTS runs at $\sim 0.4-0.7$ wt. $\% \mathrm{H}_{2} \mathrm{O}_{i}$ (Fig. 5 c), and VFR is best matched by $\sim 0.5-1.0$ wt. $\% \mathrm{H}_{2} \mathrm{O}_{i}$

287 (Fig. 5d). All data are better matched for model runs with low to moderate pressures $(\sim 0.10-0.15$ $288 \mathrm{GPa})$.

\subsection{Effect of water on seismic properties}

Water affects the MELTS-predicted bulk fractioned solids (Fig. 6), which can lead to

292 detectable differences in geophysical properties. To illustrate the effects of water on crustal

293 seismic velocities, we calculate seismic velocities (Fig. 7) for the MELTS-predicted bulk

294 fractionated solids (e.g., Fig. 6) at various crystal extents and initial water contents. In all runs,

295 early crystallizing phases are very mafic with relatively high seismic velocities, which decrease

296 with continuing crystallization. At a given crystal fraction, higher $\mathrm{H}_{2} \mathrm{O}_{i}$ contents produce

297 compositions with higher estimated $V_{\mathrm{P}}$ values, with an increase of $\sim 0.2-0.3 \mathrm{~km} / \mathrm{s}$ for the first $\sim 1$ 
wt. $\% \mathrm{H}_{2} \mathrm{O}_{i}$. Further addition of water leads to smaller increases in $\mathrm{V}_{\mathrm{P}}$ (an additional $\sim 0.1 \mathrm{~km} / \mathrm{s}$

299 for the next $\sim 1$ wt. $\% \mathrm{H}_{2} \mathrm{O}_{i}$ ). Lower-crustal velocities determined by Arai and Dunn (2014),

300 which are averages of the lowermost $2 \mathrm{~km}$ of crust just above the Moho taken every $\sim 8 \mathrm{~km}$ along

301 their seismic profiles, show mean differences in $V_{P}$ of a similar magnitude, from $\sim 7.0-7.2 \mathrm{~km} / \mathrm{s}$

302 in Domain III to $7.2-7.4+\mathrm{km} / \mathrm{s}$ in Domain II.

Despite uncertainties in both the thermodynamic modeling and the determination of $\mathrm{V}_{\mathrm{P}}$,

304 there is excellent agreement between the estimated and observed seismic velocities at water

305 contents that best match lava evolution trends. Best-fit model runs for Domain III and Domain II

306 lava compositions, crystallized to $\sim 20-25 \%$ to approximate the extent of the lower crust over

307 which the seismic averages were taken, predict seismic velocities $\sim 7.1 \mathrm{~km} / \mathrm{s}$ and $\sim 7.2-7.4+\mathrm{km} / \mathrm{s}$, 308 respectively.

\section{$310 \quad 4.0$ Discussion}

311 Our results from MELTS modeling suggest that even relatively low to moderate water

312 enrichments $\left(\sim 0.5-1.0\right.$ wt. $\left.\% \mathrm{H}_{2} \mathrm{O}\right)$ can produce important changes in differentiation processes

313 and seismically-detectable changes in crustal structure. MELTS model runs are sensitive to the

314 effects of water even at very low ( 0.2-0.5 wt. \%) water contents. A number of studies have

315 emphasized the importance of even small amounts of water $\left(<0.5\right.$ wt. $\left.\% \mathrm{H}_{2} \mathrm{O}\right)$ in the

316 crystallization process of MORB (e.g., Danyushevsky 2001; Asimow et al., 2004), although

317 more experiments are needed to better quantify these effects, resolve discrepancies, and improve

318 calibration of thermodynamic models (e.g., Médard and Grove, 2008; Almeev et al., 2012).

The modeling results broadly agree with previous studies indicating higher water

320 contents in the south of the Lau Basin (e.g., Kelley et al., 2006; Michael et al., 2011), though the 
321 best-fit model runs for the VFR tend to have lower parental $\mathrm{H}_{2} \mathrm{O}$ on average than previous

322 estimates. Because VFR lavas are highly differentiated, their primary magma water contents are

323 difficult to reconstruct and such efforts are complicated by degassing, diffusion or other

324 modification in melt inclusions, and contamination by seawater; direct measurements of water

325 data from these samples is limited and mostly come from ELSC samples. Hahm et al. (2012)

326 find dissolved $\mathrm{H}_{2} \mathrm{O}$ concentrations of $0.23-0.24$ wt. \% in lavas from the northern ELSC

327 segments. Bézos et al. (2009) identify a "high $\mathrm{H}_{2} \mathrm{O}$ " group within ELSC1 with water contents up

328 to $\sim 1.5$ wt. $\%$ (at $\sim 8.5$ wt. $\% \mathrm{MgO}$ ), however we note that this group comes from the southern

329 end of the ridge segment near the OSC - samples from the OSC limbs show clear deviations

330 from the main ridge segments and were removed from our main dataset and modeled separately

331 (see below). Melt inclusions from near-axis seamounts at the southern end of the VFR have

332 measured water concentrations up to 2.4 wt. $\% \mathrm{H}_{2} \mathrm{O}$ in lavas with $\sim 0.55-0.65$ wt. $\% \mathrm{H}_{2} \mathrm{O}$

333 (Kamenetsky et al., 1997). There are few other published analyses of water contents on the

334 VFR, and most reported estimates for Domain II and the transitional crust are calculated from K

335 (Michael et al., 2011) or Ti (Kelley et al., 2006) values and assuming constant ratios to $\mathrm{H}_{2} \mathrm{O}$.

336 Measured and calculated $\mathrm{H}_{2} \mathrm{O}$ contents from ELSC and VFR glass samples range from 0.2-2.5

337 wt. \% on the ELSC to 2-5 wt. \% on the VFR (Michael et al., 2011). However, these high values

338 may in part reflect differentiation, particularly for the evolved lavas in Domain II. In addition,

339 the Michael et al. (2011) study focused largely on seamounts and may represent more extreme

340 compositions than typically found on the ridge (e.g., Kamenetsky et al., 1997; Haase et al.,

341 2009). We also note that there is an inherent difference in the scale of sampling between such

342 petrological studies, which represent spot-analyses of glass or rocks from a few locations, and

343 the seismic study results, which are averaged over $2 \mathrm{~km} \times 8 \mathrm{~km}$. 
Estimates of mantle source $\mathrm{H}_{2} \mathrm{O}$ contents in the Lau Basin based on mantle melting

345 models also show a strong gradient between the northern and southern spreading segments,

346 ranging from a mean source $\mathrm{H}_{2} \mathrm{O}$ of $\sim 0.04$ for the ELSC (all segments) to $\sim 0.22 \mathrm{wt} . \%$ in the

347 VFR (Kelley et al., 2006). Harmon and Blackman (2010) also explore source water contents and

348 mantle potential temperature in the Lau back-arc region with 2-D numerical models of regional

349 mantle flow, thermal structure and melting, and require a source $\mathrm{H}_{2} \mathrm{O}>0.22$ wt.\% to match

350 observed crustal thickness and lava water contents for the VFR, with substantially less water for

351 the northern ELSC. While it is difficult to draw direct comparisons between these different data

352 types and proxies, results are generally consistent in requiring higher water contents along the

353 VFR, with even more extreme compositions measured in off-axis seamounts.

The modeling is less sensitive to pressure than composition. Where AMC reflectors are

355 observed in seismic reflection surveys (ELSC3-4 and VFR), their depth ranges from $\sim 2-3 \mathrm{~km}$

356 (Jacobs et al., 2007), in good agreement with the low-to-moderate best-fit fractionation pressures

357 modeled. This does not preclude some crystallization also occurring in the lower crust -

358 eruptions are most likely to sample material from the shallow parts of the magmatic system and

359 lava samples are therefore biased to the final (shallowest) crystallization pressures, particularly

360 in the presence of a steady-state melt lens. Numerous studies of MORB (e.g., Grove et al., 1992;

361 Herzberg, 2004; Eason and Sinton, 2006) and their phenocryst-hosted melt inclusions (e.g.,

362 Wanless and Shaw, 2012; Wanless et al., 2015) suggest that crystallization occurs over a range of

363 depths. ELSC2, which lacks an AMC reflector, is the only segment to show poor fits at low

364 pressure $\left(\sim 0.05 \mathrm{GPa}\right.$ and less). We note that samples from ELSC2 have lower $\mathrm{CaO} / \mathrm{Al}_{2} \mathrm{O}_{3}$ for

365 their $\mathrm{MgO}$ than the other segments, indicating a slightly earlier onset of clinopyroxene

366 fractionation, which can be indicative of high pressure crystallization. Most but not all samples 
367 from the $\mathrm{OSC}$ also have slightly lower $\mathrm{CaO} / \mathrm{Al}_{2} \mathrm{O}_{3}$ on average for their $\mathrm{MgO}$, perhaps indicating 368 higher crystallization pressures.

Implicit in the MELTS modeling is the assumption that crustal assimilation and

370 contamination does not play an important role in generating the observed major element

371 compositional trends. Although crustal assimilation and/or magma mixing are frequently called

372 upon as mechanisms for generating evolved lava compositions in arc settings, we do not see

373 evidence for assimilation or magma mixing playing a significant role in the major element oxide

374 trends. Recent studies addressing the role of crustal contamination processes find stronger $\mathrm{Cl}$

375 enrichments relative to $\mathrm{K}_{2} \mathrm{O}, \mathrm{H}_{2} \mathrm{O}$ and $\mathrm{TiO}_{2}$ and other slab-derived components in basaltic

376 samples from the ELSC than in VFR samples, consistent with crustal assimilation of Cl-rich

377 altered oceanic crust material in Domain III (Kent et al., 2002; Hahm et al, 2012). We also note

378 the lack of correlation between $\mathrm{MgO}$ and ${ }^{87} \mathrm{Sr} /{ }^{86} \mathrm{Sr}$ (Escrig et al., 2009), which one might expect

379 if assimilation of altered oceanic crust were playing an important role in generating high magma

$380 \mathrm{SiO}_{2}$ contents. A similar investigation into the generation of silicic crust at back-arc spreading

381 centers in the Manus Basin also found a lack of evidence for assimilation of altered oceanic

382 crust, and concluded that it must play a minor role, if any, in generating the broad compositional

383 spectrum (50-75 wt. \% $\mathrm{SiO}_{2}$ ) found there (Beier et al., 2015). While we cannot rule out some

384 assimilation and contamination of altered crust or gabbro, we find no evidence that such a

385 process contributes significantly to the composition of the eruptive products.

386 By excluding samples near OSCs and other ridge offsets, we have by coincidence

387 removed samples in the otherwise fairly 'dry' Domain III that show enrichments of a wet slab-

388 derived component (Bézos et al., 2009). While this allows us to better characterize the more

389 'typical' compositions and processes operating along the northernmost ridge segments, these 
390 deviations are striking. While the MELTS modeling is not very pressure-sensitive, the group of

391 samples from the OSC limbs of Domain III are best fit by model runs that are both higher

392 pressure and higher water content than the rest of Domain III (Supplementary Material, Fig. S4).

393 Some of these samples exhibit the high-Al, low-Si signature characteristic of samples near the

394 ends of ridge segments from mid-ocean ridges worldwide (e.g., Eason and Sinton, 2006), and

395 may reflect higher average pressures of crystallization than at ridge segment centers. Dry

396 versions of these high-Al, low-Si basalts are strongly associated with regions of low magma

397 supply, such as near ridge terminations, fracture zones, and at slow spreading centers, and are

398 thought to be related to enhanced conductive cooling in these regions (e.g., Herzberg, 2004;

399 Eason and Sinton, 2006).

400 While higher crystallization pressures may play a role in generating these OSC samples, 401 their elevated $\mathrm{H}_{2} \mathrm{O}$ (Bézos et al., 2009), Ba/Th (Fig. 3) and similar enrichments of fluid-mobile

402 elements also require higher contributions from a subduction-related source. This does not

403 appear to be along-axis mixing from the wetter ELSC2; seismic imaging of the crustal magmatic

404 system at this $\mathrm{OSC}\left(20^{\circ} 10^{\prime} \mathrm{S}\right)$ shows that the low velocity regions associated with the two ridge

405 limbs are discontinuous down to at least $\sim 5 \mathrm{~km}$ depth, indicating the crustal magmatic system

406 and the bulk of the associated thermal anomalies are distinct throughout the mid-to-upper crust

407 (Dunn et al., 2013). Further south in Domain II, Sleeper and Martinez (2014) also noted a

408 correlation between OSCs and geochemical tracers of subduction input, and suggested that the

409 OSCs lie along slab trajectories from arc volcanoes and represent "hot fingers" of more hydrous

410 melting in the mantle wedge (e.g., Tamura et al., 2002).

411 We suspect that the geochemical processes and signatures seen at segment ends are

412 actually present to some extent all along the segment, but get swamped by the more robust 
413 magma systems and greater degree of magma mixing at the segment center. The less abundant,

414 enriched subduction-related mantle components may be more easily sampled in areas that lack a

415 persistent, melt-dominated system. We also note that this region sits on the edge of the crustal

416 transition and appears to have switched from generating Domain III-like crust to wetter,

417 transitional crust and back several times in recent history (Fig. 1). Regional mantle imaging

418 indicates this is approximately the latitude at which the low velocity anomalies in the mantle

419 under the volcanic arc and the spreading centers transition from being connected (at $\sim 20-35 \mathrm{~km}$

420 depth) to distinct (within the resolution of the imaging) (Zha et al., 2014).

\subsection{Effects of water on physical processes}

In addition to modifying the crystallizing phase proportions of an evolving magma, the

424 presence of water also affects magma density, with consequences for melt separation and

425 eruption. Water lowers the density of magma relative to a dry magma of an otherwise equivalent

426 composition (e.g., Grove and Baker, 1983). This effect increases as the magma evolves due to

427 the incompatible behavior of water, which leads to increasing concentration in the residual melts

428 and further suppression of plagioclase crystallization relative to denser phases. Density

429 calculations from the MELTS model runs illustrate this effect: Figure 8 shows the density of the

430 residual melt as a function of $\mathrm{MgO}$ for various water contents as well as the difference between

431 the bulk solid and liquid densities, plotted as \% of bulk solid. Higher water contents lead to

432 lower liquid densities (Fig. 8a) and significantly larger density differences between the

433 fractionated solid phases and the residual melt - up to almost $20 \%$ for the best-fit VFR model

434 runs (Fig. 8b). This has important implications for melt segregation, since larger density

435 differences may lead to more efficient melt separation and buoyant rise. This may help 
436 contribute to the unusually strong chemical stratification inferred from the seismic structure of

437 Domain II. In combination with the generally higher magma supply found in Domain II and the

438 transitional region, enhanced melt segregation may assist in the development of the shallow

439 AMC seismically imaged all along the ridge axis in these regions, where melt accumulates in

440 sufficient quantities to produce strong reflectors (Harding et al., 2000; Jacobs et al., 2007).

441 Across-axis seismic tomography profiles (Dunn et al., 2013) show what appears to be a very

442 narrow magmatic system beneath ELSC4 that extends to shallow depths ( $2 \mathrm{~km})$ with the

443 seismically-imaged melt lens near the top, while the low-velocity zones underlying Domain III

444 are broader and deeper (up to $\sim 3-4 \mathrm{~km}$ depth). Results from mantle Rayleigh wave tomography

445 also suggests mantle melt extraction is more efficient for the ridge segments near the arc, as the

446 low seismic velocity anomalies are weaker in the south indicating lower melt retention (porosity)

447 despite an increase in melt supply to the ridge (Wei et al., 2015).

Density effects may contribute to the distinct distribution of lavas found along the water-

449 rich segments versus the dry Domain III, as well (Fig. 8c). The coincidence of low MgO lavas

450 on segments with a crustal melt lens primarily reflects low temperature differentiation made

451 possible by maintaining long-lived magma bodies in the shallow crust. However, Domain II

452 lavas are even more differentiated on average than typical MORB from the Eastern Pacific Rise

453 or other fast-spreading ridges that exhibit long-lived AMCs, indicating these magmas often

454 remain eruptible at lower MgO. Typical dry MORB magmas reach a density minimum at the

455 point of plagioclase saturation ( $\sim 8 \mathrm{wt} . \% \mathrm{MgO})$, which is close to a typical MORB composition

456 (e.g., Stolper and Walker, 1980). Once plagioclase starts to fractionate, the melt density

457 increases (Fig. 1a), quickly approaching densities for typical basaltic crust and making eruption

458 more difficult. While more evolved lavas do sometimes erupt along mid-ocean ridges, they are 
much more rare, and tend to be associated with unusual settings (e.g., ridge terminations, plume-

460 influenced ridge segments). However, lavas erupted in the near-arc regions of the ELSC and

461 VFR are much more evolved than typical MORB, spanning from $\sim 1$ to $>7$ wt. $\% \mathrm{MgO}$ with an

462 average of $\sim$ wt. \% (Fig. 8c). As first noted by Asimow et al. (2005), MELTS model runs with

$463 \mathrm{H}_{2} \mathrm{O}_{i}>\sim 0.4$ show calculated liquid densities continue to decrease with continued crystallization,

464 even after plagioclase saturation (Fig. 8a). While other factors such as magma supply

465 (overpressure), volatile exsolution, and viscosity will also play significant roles in controlling

466 eruption, their decreasing density may help keep these water-rich magmas buoyant and eruptible

467 even to very evolved compositions.

\subsection{Crustal formation at back-arcs}

Arai and Dunn (2014) proposed that the high-velocity lower crust observed in seismic

471 experiments in the Lau back-arc basin could be explained by the presence of water and its

472 predicted effects on magmatic differentiation, and we have now shown the feasibility of that

473 model. We believe this mechanism provides the best current explanation for the high-velocity

474 lower crust and thick, low velocity upper crust. Additionally, changes in physical properties of

475 the magma due to the presence of water (i.e., density and viscosity) may further contribute to

476 generating strongly fractionated crust.

477 Oceanic crust with a high velocity lower crust has been imaged in the Yamato Basin in

478 the Japan Sea, with a crustal thickness of $\sim 10-15 \mathrm{~km}$ and up to $7.4 \mathrm{~km} / \mathrm{s}$ wave speeds in the

479 lowermost crust (Sato et al., 2014). There it is proposed to form via underplating of ultramafic

480 material due to an anomalously hot asthenosphere during the opening of the basin (Sato et al.,

481 2014; Hirahara et al., 2015), similar to high velocity lower crust adjacent to continental margins 
482 (e.g., Kodaira et al., 1995). While high mantle potential temperature is thought to be a

483 mechanism for generating ultramafic lower crust (e.g., Kelemen and Holbrook, 1995; Korenaga

484 et al., 2000, 2002), this is unlikely in the Lau basin, since estimated mantle potential

485 temperatures are lower in the south where the anomalous Domain II crust is currently forming

486 (Kelley et al., 2006; Wiens et al., 2006; Wei et al., 2015). An analysis by Kelley et al. (2006)

487 suggests that, while mantle potential temperature seems to be responsible for most excess melt

488 generation (and correspondingly thick crust) beneath many back-arc basins, the Lau back-arc

489 appears to be an exception, showing a steep linear increase in extent of melting with mantle

490 source $\mathrm{H}_{2} \mathrm{O}_{0}$. This is further supported by Harmon and Blackman (2010), who modeled mantle

491 flow, thermal structure and melting at Lau back-arc spreading centers and found that differences

492 in source water content $\left(0.15\right.$ wt. $\%$ and $>0.22$ wt. $\% \mathrm{H}_{2} \mathrm{O}_{0}$ for the ELSC and VFR, respectively),

493 not potential temperature $\left(1300^{\circ} \mathrm{C}\right.$ for both), best explain the observed differences in crustal

494 thickness between the VFR and ELSC. Furthermore, we note that Domain II lavas have

495 relatively lower fractionation-corrected $\mathrm{FeO}$ contents than Domain III (Fig. 4), which is

496 inconsistent with predictions for higher potential temperatures; melting runs using pMELTS

497 (Ghiorso et al., 2002) indicate that the temperature increase required to produce a 2-3 $\mathrm{km}$

498 increase in crustal thickness also produces a 1-2\% increase in fractionation-corrected FeO (e.g.,

499 Asimow and Langmuir, 2003) due to Fe's pressure sensitivity (e.g., Langmuir and Hanson, 1980;

500 Klein and Langmuir, 1987). Modest increases in source water content, on the other hand, can

501 produce the same increase in crustal thickness while predicting slightly lower FeO contents

502 (Asimow and Langmuir, 2003), consistent with Domain II lava compositions. This also

503 distinguishes Lau from the Yamato Basin, where thick back-arc crust is associated with

504 significantly higher $\mathrm{FeO}$ contents $(\sim 8-11+$ wt. \% FeO vs. 5-7.8 wt. \% FeO at similar MgO) 
505 (Hirahara et al., 2015), and suggests that processes might vary significantly between back-arc 506 basins.

The Lau back-arc is thought to be unusually water-rich compared to other back-arcs

508 globally (e.g., Kelley et al., 2006), perhaps in part due to fast convergence rates. However, our

509 MELTS calculations suggest that even moderate amounts of water $(>0.5$ wt. \%) in the parental

510 magma may have an observable effect on the seismic structure. It is possible this process plays a

511 role in other water-rich back-arcs (e.g., Havre Trough, Mariana Trough, Manus Basin), as well as

512 contributes to the crustal structure of the arcs themselves (e.g., Aleutian arc, Izu-Bonin-Mariana

513 arc) where deep high velocity lower crusts have been observed (e.g., Shillington et al., 2004;

514 Behn and Kelemen, 2006; Kodaira et al., 2007; Takahashi et al., 2008, 2009).

\section{$516 \quad 5.0$ Conclusions}

Slab-derived water leads to increases in melt supply and crustal thickness at back-arc

518 spreading center segments close to the active arc $(<50 \mathrm{~km})$. In this study, we demonstrate that

519 water can also produce significant changes in the seismic structure of the oceanic crust produced

520 along the ELSC and VFR in the eastern Lau Basin. We model magma differentiation paths using

521 thermodynamic models of phase equilibria, comparing modeled liquid compositional trends

522 against analyzed sample compositions from individual ridge segments. Predicted crystallizing

523 assemblages and mineral compositions are also used to calculate seismic wave speeds of the

524 lower crust for comparison with seismic tomography results. Compositional trends from lavas

525 erupted along the northern ELSC $>70 \mathrm{~km}$ from the active arc are best matched by MELTS runs

526 with low initial water contents $\left(\sim 0.2\right.$ wt. $\left.\% \mathrm{H}_{2} \mathrm{O}_{i}\right)$, while higher water contents $(\sim 0.5-1.0$ wt. $\%$

$\left.527 \mathrm{H}_{2} \mathrm{O}_{i}\right)$ are required to match lava compositions along the VFR $(<50 \mathrm{~km}$ from the arc $)$. Best-fit 
528 model runs for the VFR also have more mafic early crystallizing phases due to the presence of

529 water, with calculated seismic velocities of $\sim 7.2-7.4+\mathrm{km} / \mathrm{s}$ at solid fractions that approximate the

530 volume of the lower crust, consistent with the anomalously high seismic velocities imaged there.

531 We present a petrological model of crustal formation along back-arc spreading centers in the

532 Eastern Lau Basin, in which slab-derived water close to the arc suppresses plagioclase

533 crystallization and leads to the formation of an ultramafic lower crust with high seismic

534 velocities, while successfully predicting major element compositional trends of the erupted lavas.

\section{Acknowledgements}

538 We wish to thank Fernando Martinez and John Sinton for helpful discussions and 539 feedback, as well as two anonymous reviewers for their constructive comments. This work was 540 funded by NSF grant OCE0426428. This is SOEST contribution \#9480.

\section{References}

546 Aggrey, K.E., D.W. Muenow, J.M. Sinton (1988) Volatile abundances in submarine glasses from 547 the North Fiji and Lau back-arc basins. Geochim. Cosmochim. Acta 52: 2501-2506.

548 Almeev, R.R., F. Holtz, J. Koepke, F. Parat (2012) Experimental calibration of the effect of $\mathrm{H}_{2} \mathrm{O}$ 549 on plagioclase crystallization in basaltic melt at 200 MPa. Amer. Mineral. 97: 1234-1240. 
Antoshechkina, P.M., P.D. Asimow (2010) alphaMELTS 3.0 and the MAGMA website: educational and research tools for studying the petrology and geochemistry of plate margins, Abstract ED41B-0644 presented at 2010 Fall Meeting, AGU, San Francisco, CA, 13-17 Dec.

Antoshechkina, P.M., P.D. Asimow, E.H. Hauri, P.I. Luffi (2010) Effect of water on mantle melting and magma differentiation, as modeled using alphaMELTS 3.0, Abstract V53C2264 presented at 2010 Fall Meeting, AGU, San Franisco, CA, 13-17 Dec.

Arai, R., R. Dunn (2014) Seismological study of Lau back arc crust: Mantle water, magmatic differentiation, and a compositionally zoned basin. Earth Planet. Sci. Lett. 390, doi:10.1016/j.epsl2014.01.014.

Asimow, P.D., M.S. Ghiorso (1998) Algorithmic modifications extending MELTS to calculate subsolidus phase relations, American Mineralogist, 83 (9-10), 1127-1132.

Asimow, P.D., C.H. Langmuir, and the Kilo Moana 0417 Shipboard Science Party (2005) Effect of water on magma and crustal density: Highly fractionated lavas in the Lau Basin and other

wet spreading centers. 2005 Goldschmidt Conference, Moscow, Idaho. Geochim. et Cosmochim. Acta 69(10 supplement): A149.

Asimow, P.D., J.E. Dixon, C.H. Langmuir (2004) A hydrous melting and fractionation model for mid-ocean ridge basalts: Application to the Mid-Atlantic Ridge near the Azores. Geochem. Geophys. Geosyst. 5: 1-24.

Austin, R. (2012) Early seafloor spreading and variations in crustal accretion in the Lau basin, University of Hawaii graduate thesis, University of Hawaii, Honolulu, HI. 
571 Behn, M.D., P.B. Kelemen (2003) Relationship between seismic P-wave velocity and the 572 composition of anhydrous igneous and meta-igneous rocks. Geochem. Geophys. Geosyst. 4, doi:10.1029/2002GC000393.

574 Behn, M.D., P.B. Kelemen (2006) Stability of arc lower crust: Insights from the Talkeetna arc section, south central Alaska, and the seismic structure of modern arcs. J. Geophys. Res.

Beier, C., W. Bach, S. Turner, D. Niedermeier, J. Woodhead, J. Erzinger, S. Krumm (2015) Origin of silicic magmas at spreading centres — an example from the South East Rift, Manus Basin. J. Petrol. 56: 255-272.

Bézos, A., S. Escrig, C.H. Langmuir, P.J. Michael, P.D. Asimow (2009) Origins of chemical diversity of back-arc basin basalts: A segment-scale study of the Eastern Lau Spreading 111, doi10.1029/2006JB004327. Center. J. Geophys. Res. 114, B06212, doi:10.1029/2008JB005924.

Danyushevsky, L.V. (2001) The effect of small amounts of $\mathrm{H}_{2} \mathrm{O}$ on crystallization of mid-ocean ridge and backarc basin magmas. J. Volcanol. Geotherm. Res. 110: 265-280.

Davies, J.H., M.J. Bickle (1991) A physical model for the volume and composition of melt produced by hydrous fluxing above subduction zones. Phil. Trans. R. Soc. London A 335: $355-364$.

Dunn, R.A., D. Forsyth (2007) Crust and Lithospheric Structure - Seismic Structure of MidOcean Ridges. In Treatise on Geophysics, eds. A. Dziewonski and B. Romanowicz, Elsevier Science Ltd., 6054 pp.

Dunn, R.A., F. Martinez (2011) Contrasting crustal production and rapid mantle transitions beneath back-arc ridges. Nature 469, 198-202, doi:10.1038/nature09690. 
Dunn, R.A., F. Martinez, J.A. Conder (2013) Crustal construction and magma chamber properties along the Eastern Lau Spreading Center, Earth Planet. Sci. Lett. 371-372: 112124.

Eason, D.E., J.M. Sinton, 2006. Origin of high-Al N-MORB by fractional crystallization in the upper mantle beneath the Galápagos Spreading Center. Earth Planet. Sci. Lett. 252: 423-436.

Escrig, S., A. Bézos, S.L. Goldstein, C.H. Langmuir, P.J. Michael (2009) Mantle source variations beneath the Eastern Lau Spreading Center and the nature of subduction components in the Lau basin-Tonga arc system. Geochem. Geophys. Geosyst. 10, Q04014, doi:10.1029/2008GC002281.

Gaetani, G.A., T.L. Grove, W.B. Bryan (1994) Experimental phase relations of basaltic andesite from hole 839B under hydrous and anhydrous conditions. in: Hawkins, J., Parson, L. Allan, J. (Eds.), Proceedings of the Ocean Drilling Program Leg 135, Scientific Results. Ocean Drilling Program, College Station, TX, pp. 557-563.

Gale, A., C.A. Dalton, C.H. Langmuir, Y. Su, J.-G. Schilling (2013) The mean composition of ocean ridge basalts. Geochem. Geophys. Geosyst. 14, doi:10.1029/2012GC004334.

Ghiorso, M.S., R.O. Sack (1995). Chemical Mass-Transfer in Magmatic Processes IV. A Revised and Internally Consistent Thermodynamic Model for the Interpolation and Extrapolation of Liquid-Solid Equilibria in Magmatic Systems at Elevated-Temperatures and Pressures. Contrib. to Min. Pet. 119(2-3): 197-212.

Ghiorso, M.S., M.M. Hirschmann, P.W. Reiners, V.C. Kress (2002) The pMELTS: A revision of MELTS for improved calculation of phase relations and major element partitioning related to partial melting of the mantle to 3GPa. Geochem. Geophys. Geosyst. 3: doi:10.1029/2001GC000217. 
616 Grove, T.L., M.B. Baker (1983) Effects of melt density on magma mixing in calc-alkaline series $617 \quad$ lavas. Nature, 305: 416-418.

618 Grove, T.L., R. Kinzler, W. Bryan (1992) Fractionation of mid-ocean ridge basalts, in: J. Phipps619 Morgan, D. Blackman, J. Sinton (Eds.), Mantle Flow and Melt Generation at Mid-Ocean 620 Ridges. Geophys. Monogr. Ser., vol 71, AGU, Washington DC, pp. 281-310.

621 Haase, K.M., S. Fretzdorff, R. Mühe, D. Garbe-Schönberg, P. Stoffers (2009) A geochemical 622 study of off-axis seamount lavas at the Valu Fa Ridge: Constraints on magma genesis and slab contributions in the southern Tonga subduction zone. Lithos 112: 137-148.

Hacker, B.R., G.A. Abers (2004) Subduction factory 3: An Excel worksheet and macro for calculating densities, seismic wave speeds, and $\mathrm{H}_{2} \mathrm{O}$ contents of minerals and rocks at pressure and temperature. Geochem. Geophys. Geosyst. 5, doi:10.1029/2003GC000614.

Hacker, B.R., G.A. Abers, S.M. Peacock (2003) Subduction factory; 1, Theoretical mineralogy, densities, seismic wave speeds, and $\mathrm{H}_{2} \mathrm{O}$ contents. J. Geophys. Res 108, doi:10.1029/2001JB001127.

Hahm, D., D.R. Hilton, P.R. Castillo, J.W. Hawkins, B.B. Hanan, E.H. Hauri (2012) An overview of the volatile systematics of the Lau Basin — Resolving the effects of source variation,

633 Harding, A.J., G.M. Kent, J.A. Collins (2000) Initial results from a multichannel seismic survey of the Lau back-arc basin. EOS Trans., AGU, 81(48), Fall Meet. Suppl., Abstract T61C-16. mantle melting beneath the back-arc spreading centers along the Lau Basin. Earth Planet. Sci. Lett. 298: 334-346. 
Hawkins, J.W. (1994) Petrologic synthesis: Lau Basin Transect (Leg 135). In: Hawkins, J., Parson, L., Allan, J. (Eds.), Proceedings of the Ocean Drilling Program Leg 135, Scientific Results. Ocean Drilling Program, College Station, TX, pp. 879-905.

Hawkins, J.W. (1995) Evolution of the Lau Basin: Insights from ODP leg 135. in: Taylor, B., Natland, J. (Eds.), Active margins and marginal basins of the western Pacific. Geophys. Monogr. Ser. 88, AGU, Washington, D.C., pp.125-173.

Hawkins, J.W., L.M. Parson, J.F. Allan (1994) Introduction to the scientific results of Leg 135: Lau Basin-Tonga Ridge drilling transect. In: Hawkins, J.W., Parson, L.M., Allan, J. (Eds.), Proceedings of the Ocean Drilling Program Leg 135, Scientific Results. Ocean Drilling Program, College Station, TX, pp. 3-5.

Herzberg, C. (2004) Partial crystallization of mid-ocean ridge basalts in the crust and mantle. J. Petrol. 45: 2389-2405.

Hirahara, Y., J.-I. Kimura, R. Senda, T. Miyazaki, H. Kawabata, T. Takahashi, Q. Chang, B.S. Vaglarov, T. Sato, S. Kodaira (2015) Geochemical variations in Japan Sea back-arc basin basalts formed by high-temperature adiabatic melting of the mantle metasomatized by sediment subduction components. Geochem. Geophys. Geosyst. 16: 1324-1347, doi:10.1002/2015GC005720.

Jacobs, A.M., A.J. Harding, G.M Kent (2007) Axial crustal structure of the Lau back-arc basin from velocity modeling of multichannel seismic data. Earth Planet. Sci. Lett. 259: 239-255.

Kamenetsky, V.S., A.J. Crawford, S. Eggins, R. Muhe (1997) Phenocryst and melt inclusion chemistry of near-axis seamounts, Valu Fa Ridge, Lau basin: Insight into mantle wedge melting and the addition of subduction components. Earth Planet. Sci. Lett. 151:205-223, doi:10.1016/S0012-821X(97)81849-3. 
661 Kelemen, P., W. Holbrook (1995) Origin of thick, high-velocity igneous crust along the U.S. East 662 Coast margin. J. Geophys. Res. 100: 10,077-10,094.

663 Kelley, K.A., T. Plank, T.L. Grove, E.M. Stolper, S. Newman, E. Hauri (2006) Mantle melting as 664 a function of water content beneath back-arc basins. J. Geophys. Res. 111, B09208, 665 doi:10.1029/2005JB003732.

Kent, A.J.R., D.W. Peate, S. Newman, E.M. Stolper, J.A. Pearce (2002) Chlorine in submarine glasses from the Lau Basin: Seawater contamination and constraints on the composition of slab-derived fluids. Earth Planet. Sci. Lett. 202: 361-377.

Klein, E.M., C.H. Langmuir (1987) Global correlations of ocean ridge basalt chemistry with axial depth and crustal thickness. J. Geophys. Res. 92: 8089-8115.

Kodaira, S., A. Goldschmidt-Rokita, J.M. Hartmann, H.B. Hirschleber, T. Iwasaki, T. Kanazawa, H. Krahn, S. Tomita, H. Shimamura (1995) Crustal structure of the Lofoten continental margin, off northern Norway, from ocean-bottom seismographic studies. Geophys. J. Int. 121: 907-924.

Kodaira, S., T. Sato, N. Takahashi, A. Ito, Y. Tamura, Y. Tatsumi, Y. Kaneda (2007)

Seismological evidence for variable growth of crust along the Izu intraoceanic arc. J. Geophys. Res. 112, B05104, doi:10.1029/2006JB004593.

Korenaga, J., W.S. Holbrook, G.M. Kent, P.B. Kelemen, R.S. Detrick, H.-C. Larsen, J.R. Hopper, T. Dahl-Jensen (2000) Crustal structure of the southeast Greenland margin from joint refraction and reflection seismic tomography. J. Geophys. Res. 105: 21,591-21,614.

Korenaga, J., P.B. Kelemen, W.S. Holbrook (2002) Methods for resolving the origin of large igneous provinces from crustal seismology. J. Geophys. Res. 107, doi:10.1029/2001JB001030. 
684 Langmuir, C.H., G.N. Hanson (1980) An evaluation of major element heterogeneity in the 685 mantle sources of basalts. Phil. Trans. R. Soc. Lond. 297: 383-407.

686 Langmuir, C.H., A. Bézos, S. Escrig, S.W. Parman (2006) Chemical Systematics and Hydrous 687 Melting of the Mantle in Back-Arc Basins. In: Back-Arc Spreading Systems: Geological, 688 Biological, Chemical, and Physical Interactions, Geophys. Mono. Series 166: 87-146.

689 Lehnert, K., Y. Su, C. Langmuir, B. Sarbas, U. Nohl (2000) A global geochemical database 690 structure for rocks. Geochem. Geophys. Geosyst. 1, doi:10.1029/1999GC000026.

691 Martinez, F., B. Taylor, (2002) Mantle wedge control on back-arc crustal accretion. Nature 416 : $692 \quad$ 417-420.

693 Martinez, F., B. Taylor, E.T. Baker, J.A. Resing, S.L. Walker (2006) Opposing trends in crustal 694 thickness and spreading rate along the back-arc Eastern Lau Spreading Center: Implications 695 for controls on ridge morphology, faulting, and hydrothermal activity. Earth Planet. Sci. Lett. $696 \quad 245: 655-672$.

697 Médard, E., T. Grove (2008) The effect of $\mathrm{H}_{2} \mathrm{O}$ on the olivine liquidus of basaltic melts:

698 experiments and thermodynamic models. Contrib. Mineral. Petrol. 155: 417-432.

699 Michael, P.J., S. Escrig, A. Bézos, C.H. Langmuir, R.J. Arculus, C.I. Goddard (2011) Along- and 700 Across-arc Basalt Geochemical Trends of Seamount in Lau Basin: Evidence for Fluid 701 Components and Mantle Melting. Abstract V54B-02 presented at 2011 Fall Meeting, AGU, 702 San Francisco, CA., 5-9 Dec.

703 Nicholls, I.A., A.E. Ringwood (1973) Effect of water on olivine stability in tholeiites and the 704 production of silica-saturated magmas in the island-arc environment. J. Geology 81: 285705300. 
Pearce, J.A. (1994) Geochemistry of Lau Basin volcanic rocks: Influence of ridge segmentation and arc proximity. Spec. Publ. Geol. Soc. London, 81: 53-75.

Pearce, J.A., R.J. Stern (2006) The origin of back-arc basin magmas: Trace element and isotope perspectives, in: Christie, D.M. et al. (Eds.), Back-Arc Spreading Systems: Geological, Biological, Chemical and Physical Interactions. Geophys. Monogr. Ser., AGU, Washington, DC, pp. 63-86.

Pearce, J.A., M. Ernewein, S.H. Bloomer, L.M. Parson, B.J. Murton, and L.E. Johnson (1994) Geochemistry of Lau Basin volcanic rocks: influence of ridge segmentation and arc proximity. Geol. Soc. London Spec. Publ. 81: 53-75. doi:10.1144/GSL.SP.1994.081.01.04.

Peate, D.W., T.F. Kokfelt, C.J. Hawkesworth, P.W. Van Calsteren, J.M. Hergt, J.A. Pearce (2001) U-series isotope data on Lau basin glasses: the role of subduction-related fluids during melt generation in back-arc basins. J. Petrol. 42: 1449-1470.

Peirce, C., A.M. Turner, M.C. Sinha (2001) Crustal structure, accretionary processes and rift propagation: a gravity study of the intermediate-spreading Valu Fa Ridge, Lau Basin. Geophys. J. Int. 146: 53-73.

Sato, T., T. No, S. Kodaira, N. Takahashi, Y. Kaneda (2014) Seismic constraints of the formation process on the back-arc basin in the southeastern Japan Sea. J. Geophys. Res. 229: 15631579, doi:10.1002/2013JB010643.

Shillington, D.J., H.J.A. Van Avendonk, W.S. Holbrook, P.B. Kelemen, M.J. Hornbach (2004) Composition and structure of the central Aleutian island arc from arc-parallel wide-angle seismic data. Geochem. Geophys. Geosyst. 5, Q10006, doi:10.1029/2004GC000715.

Sinton, J.M., P. Fryer (1987) Mariana Trough lavas from $18^{\circ} \mathrm{N}$ : Implications for the origin of back arc basin basalts. J. Geophys. Res. 92, doi:10.1029/JB080i012p12782 
729 Sinton, J.M., R.C. Price, K.T.M. Johnson, H. Staudigel, A. Zindler (1993), Petrology and

730 geochemistry of submarine lavas from the Lau and North Fiji backarc basins, in Basin

731 Formation, Ridge Crest Processes and Metallogenesis in the North Fiji Basin, Earth Sci.

732 Ser., vol. 15, edited by L. W. Kroenke, and J. V. Eads, pp. 119-135, Circum-Pac. Counc. For

733 Energy and Miner. Resour., Houston, Tex.

734 Sisson, T.W., T.L. Grove (1993) Experimental investigations of the role of H2O in calc-alkaline 735 differentiation and subduction zone magmatism. Contrib. Mineral. Petrol. 113, 143-166.

736 Sleeper, J.D. (2011) Intra-segment variations in subduction influence along the Eastern Lau

737 Spreading Center and Valu Fa Ridge, Lau Backarc Basin, SW Pacific. University of Hawaii

738 graduate thesis, University of Hawaii, Honolulu, HI.

739 Sleeper, J.D., F. Martinez (2014) Controls on segmentation and morphology along the back-arc

740 Eastern Lau Spreading Center and Valu Fa Ridge, J. Geophys. Res. 119: 1678-1700.

741 Smith, P.M., P.D. Asimow (2005) Adiabat_1ph: A new public front-end to the MELTS, pMELTS,

742 and pHMELTS models, Geochem. Geophys. Geosyst. 6, Q02004,

743 doi:10.1029/2004GC000816.

744 Stolper, E., S. Newman (1994) The role of water in the petrogenesis of Mariana trough magmas.

$745 \quad$ Earth Planet. Sci. Lett. 121: 293-325.

746 Stolper, E., D. Walker (1980) Melt density and average composition of basalt, Contrib. Mineral.

$747 \quad$ Petrol., 74: 7-12, doi:10.1007/BF00375484.

748 Takahashi, N., S. Kodaira, Y. Tatsumi, Y. Kaneda, K. Suyehiro (2008) Structure and growth of

749 the Izu-Bonin-Mariana arc crust: 1 . Seismic constraint on crust and mantle structure of the

750 Mariana arc-back-arc system. J. Geophys. Res. 113, B01104, doi:10.1029/2007JB005120. 
751 Takahashi, N, S. Kodaira, Y. Tatsumi, M. Yamashita, T. Sato, Y. Kaiho, S. Miura, T. No, K.

752 Takizawa, Y. Kaneda (2009) Structural variations of arc crusts and rifted margins in the 753 southern Izu-Ogasawara arc-back arc system. Geochem. Geophys. Geosyst. 10, Q09X08, 754 doi:10.1029/2008GC002146.

755 Tamura, Y., Y. Tatsumi, D. Zhao, Y. Kido, H. Shukuno (2002) Hot fingers in the mantle wedge:

756 New insights into magma genesis in subduction zones. Earth Planet. Sci. Lett. 197: 105-116.

757 Taylor, B., K. Zellmer, F. Martinez, A. Goodliffe (1996) Sea-floor spreading in the Lau back-arc 758 basin. Earth Planet. Sci. Lett. 144: 35-40.

759 Wanless, V.D., A.M. Shaw (2012) Lower crustal crystallization and melt evolution at mid-ocean $760 \quad$ ridges. Nature Geoscience 5: 651-655, doi:10.1038/ngeo1552.

761 Wanless, V.D., A.M. Shaw, M.D. Behn, S.A. Soule, J. Escartín, C. Hamelin (2015) Magmatic

762 plumbing at Lucky Strike Volcano based on olivine-hosted melt inclusion compositions. 763 Geochem. Geophys. Geosyst. 16: 126-147, doi:10.1002/2014GC005517.

764 Wei, S.S., D.A. Wiens, Y. Zha, T. Plank, S.C. Webb, D.K. Blackman, R.A. Dunn, J.A. Conder 765 (2015) Seismic evidence of effects of water on mantle melt transport in the Lau back-arc mantle. Nature 518: 395-398, doi:10.1038/nature14113.

767 White, R.S., D. McKenzie, R.K. O’Nions (1992) Oceanic crustal thickness from seismic measurements and rare earth element inversions. J. Geophys. Res. 97: 19,683-19,715.

769 Wiens, D.A., K.A. Kelley, T. Plank (2006) Mantle temperature variations beneath back-arc 770 spreading centers inferred from seismology, petrology, and bathymetry. Earth Planet. Sci. $771 \quad$ Lett. $248: 30-42$.

772 773 
774 Figure 1. A schematic cartoon illustrating hypothesized crustal formation processes at arc-distal

775 (Domain III) and arc-proximal (Domain II) regions of the ELSC. Figure modified from Arai and

776 Dunn (2014). In this model, slab-derived water is entrained in the ridge melting zone near the

777 active arc (right column), leading to an increase in melt supply to the ridge and producing a

778 thicker crust. As these melts cool and evolve in the crustal magmatic system (gray fields, upper

779 right), their moderately high magmatic water contents lead to suppression of plagioclase

780 crystallization relative to olivine and clinopyroxene, leading to more mafic cumulate phases

781 during the early stages of crystal fractionation. The buoyant, water-rich residual melts segregate

782 and rise into the upper crust where they form an axial melt lens (dark gray) and continue to

783 crystallize, eventually forming a thick, unusually evolved volcanic layer. Where the spreading

784 center is further than $\sim 70 \mathrm{~km}$ from the active arc (left column), the water content of melts is low

785 and water-induced differentiation is minimal.

787 Figure 2. Shaded relief map of seafloor topography in the southern Lau Basin. ELSC (Eastern

788 Lau Spreading Center) and VFR (Valu Fa Ridge) axes are shown in red. Crustal domains

789 (Martinez and Taylor, 2002; Dunn and Martinez, 2011) are outlined by dashed black lines,

790 separated by a narrow transitional zone (striped). As illustrated in Figure 1, Domain II is the

791 region of anomalous oceanic crust formed near the active arc; Domain III is the region of crust

792 formed further from the arc. (Inset) Regional map of the Lau basin and surrounding areas. Grey

793 shading indicates areas where the seafloor is shallower than $2000 \mathrm{~m}$ below sea level. Open

794 triangles indicate locations of active volcanoes of the Tofua arc. The dotted line denotes the axis

795 of the Tonga trench, which is surrounded by the 7000-m contour. Black lines show the current 
configuration of spreading centers in the Lau basin: VFR; ELSC; CLSC (Central Lau Spreading

797 Center); FR (Fonualei rift). The red box indicates area of main panel.

799 Figure 3. (a) Multibeam bathymetry of the ELSC and VFR showing sample locations (black

800 dots). (b) Axial depth profile from Martinez et al. (2006). Gray bar along the left edge denotes

801 area where magma lens reflectors are observed in along-axis multichannel seismic data (Harding 802 et al., 2000; Jacobs et al., 2007). The change in crustal type correlates with the disappearance of

803 the axial magma lens reflector and significant increase in axial depth. (c)-(e) Along-axis

804 compositional variation of $\mathrm{MgO}$ and representative trace element ratios, color-coded by ridge

805 segment. Samples from OSC limbs or near the ends of ridge segments are shown in different

806 symbols. Domain III crust includes ELSC1 (red symbols) and ELSC2 (orange); the VFR (blue)

807 currently forms Domain II crust, while ELSC3 (green) and ELSC4 (teal) make up the transitional

808 zone. (c) Along-axis variation of lava $\mathrm{MgO}$ content. Samples from Domain II and transitional

809 crust exhibit lower and more variable $\mathrm{MgO}$ contents than Domain III samples on average. (d)

810 Along-axis variation in $\mathrm{Ba} / \mathrm{Th}$ ratio, which reflects enrichment in fluid mobile elements, showing

811 high $\mathrm{Ba} / \mathrm{Th}$ in transitional and Domain II crust, with the strongest enrichments in ELSC3.

812 Samples from the limbs of ELSC1 that forms the OSC with ELSC2 at $20^{\circ} 10^{\prime} \mathrm{S}$ also show

813 enrichments in $\mathrm{Ba} / \mathrm{Th}$ relative to the main ridge segment. (e) Along-axis variation in $\mathrm{Th} / \mathrm{La}$ ratio,

814 which reflects sedimentary contribution to the arc magmas (e.g., Plank, 2005), showing an

815 increasing enrichment closer to the arc. Escrig et al. (2009) argue that the decoupling between

$816 \mathrm{Ba} / \mathrm{Th}$, which peaks in the transitional zone (Fig. 3d), and the sediment-derived component,

817 which shows a steady, gradual increase towards the south (Fig. 3e), reflects a compositional 818 change of the subduction input. 
820 Figure 4. ELSC and VFR major element oxide compositions, plotted as a function of $\mathrm{MgO}$

821 (symbols as in Figure 3). Samples from OSC limbs or near the ends of ridge segments have been

822 removed from the dataset (see text for discussion). Lines denote crystallization model runs with

823 different initial water compositions ranging from 0.0 to $1.0 \mathrm{wt}$. $\% \mathrm{H}_{2} \mathrm{O}_{i}$. Model runs shown were

824 calculated using MELTS at 0.01 GPa pressure, FMQ-2, with fractionating solid phases.

826 Figure 5. MELTS model misfits as a function of pressure and $\mathrm{H}_{2} \mathrm{O}_{i}$ content for (a) ELSC1, (b)

827 ELSC2, (c) ELSC3-4, and (d) VFR. Lower values (darker blues) denote better fits to data.

828 Misfit calculated using a total Mean Scaled Absolute Deviation normalized to spread for each

829 major element oxide-MgO pair (see text for description). ELSC1 is best matched by runs with

830 low parental water contents $(\sim 0.2 \mathrm{wt} . \%)$. While fairly insensitive to pressure, model runs with

831 higher water contents are required to match near-arc magma evolution trends, with runs with

$832 \sim 0.5-1.0$ wt. $\% \mathrm{H}_{2} \mathrm{O}_{i}$ showing the best fit to VFR (Domain II) samples.

834 Figure 6. Crystallizing phase proportions of olivine (ol), clinopyroxene (cpx) and plagioclase 835 (plag) predicted by MELTS (0.02 GPa, MOD3 starting composition, FMQ-2) as a function of 836 temperature for initial water contents of (a) 0.2 wt. \% and (b) 1.0 wt. \%. Water delays

837 crystallization of all mineral phases to slightly lower $\mathrm{T}$, but has the strongest effect on

838 plagioclase. Selected runs are at lower crustal pressures, but similar mineral relations hold at 839 shallow crustal pressures as well. 
841 Figure 7. Calculated lower crustal seismic velocities vs. parental magma water content for

842 selected extents of crystallization at $0.22 \mathrm{GPa}$ and $800^{\circ} \mathrm{C}$, consistent with cool, off-axis lower

843 crust. Lines denote $0.10,0.15,0.20$, and 0.25 solid fraction. $\mathrm{V}_{\mathrm{P}}$ is calculated from the MELTS-

844 predicted mineral mode using the method of Hacker at al. (2003) (see text for description).

845 Colored bands denote range of lower crustal velocity averages (lowermost $2 \mathrm{~km}$, comparable to a

846 solid fraction of $\sim 0.20-0.25$ ) for Domain II (blue) and Domain III (red) from Arai and Dunn

847 (2014).

848

849 Figure 8. (a) Calculated residual liquid densities and (b) density difference between bulk solid

850 and liquid (as percent of bulk solid density) vs. MgO for MELTS model runs with different

851 starting water compositions and a pressure of $\sim 0.22 \mathrm{GPa}$. Low pressure MELTS runs $(\sim 0.01$

$852 \mathrm{GPa}$ ) are nearly identical. (c) Histogram plot of lava sample MgO content for Domain III (red),

853 transitional (green) and Domain II (blue) crust. Samples from Domain II and Transitional-type

854 crust tend to have lower $\mathrm{MgO}$ contents with a distribution centered on $\sim 4$ wt. $\% \mathrm{MgO}$, while

855 Domain III samples are restricted to $>6 \mathrm{wt} . \% \mathrm{MgO}$. The liquid density of relatively dry starting

856 compositions $\left(<0.4\right.$ wt. $\left.\% \mathrm{H}_{2} \mathrm{O}_{i}\right)$ increases during crystal fractionation, quickly approaching

857 typical densities of oceanic crust and inhibiting melt ascent and eruption. The presence of water

858 in the starting liquid composition leads to a larger density contrast between the melt and

859 crystallizing phases, which may aid in the segregation, extraction and eruption of more evolved

860 lavas.

861 
Figure 1

Domain III
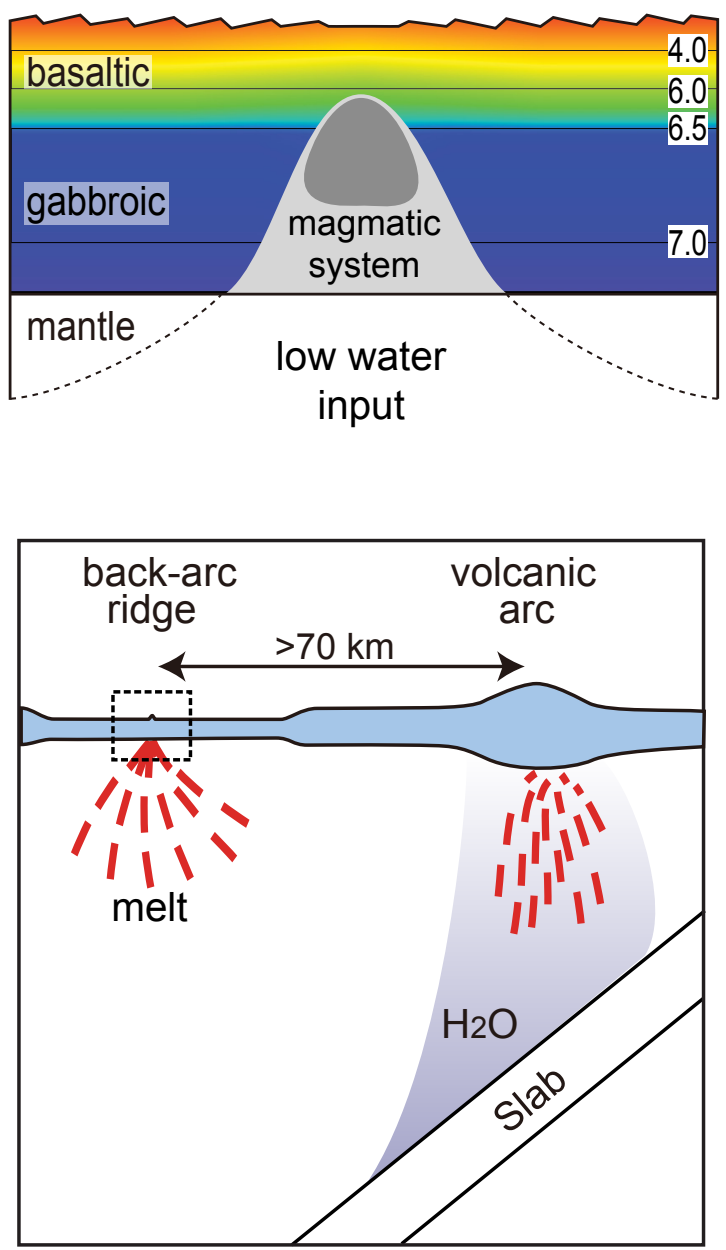

\section{Domain II}
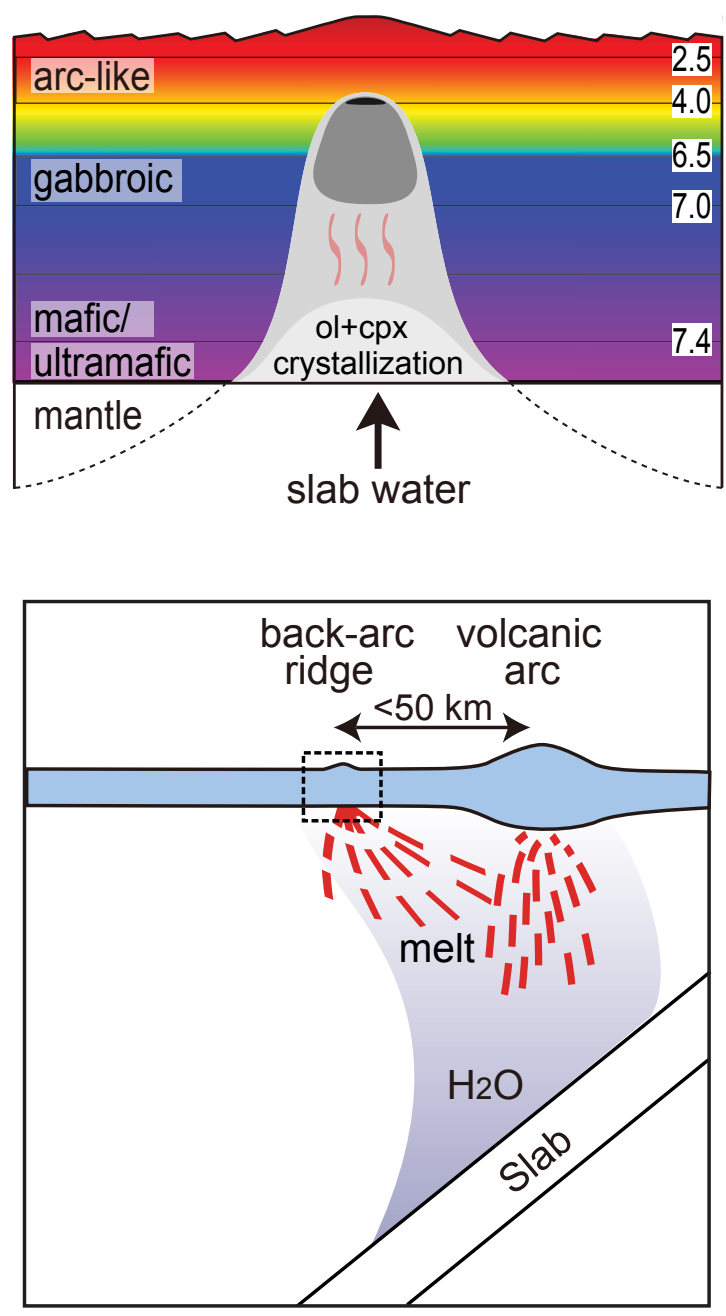


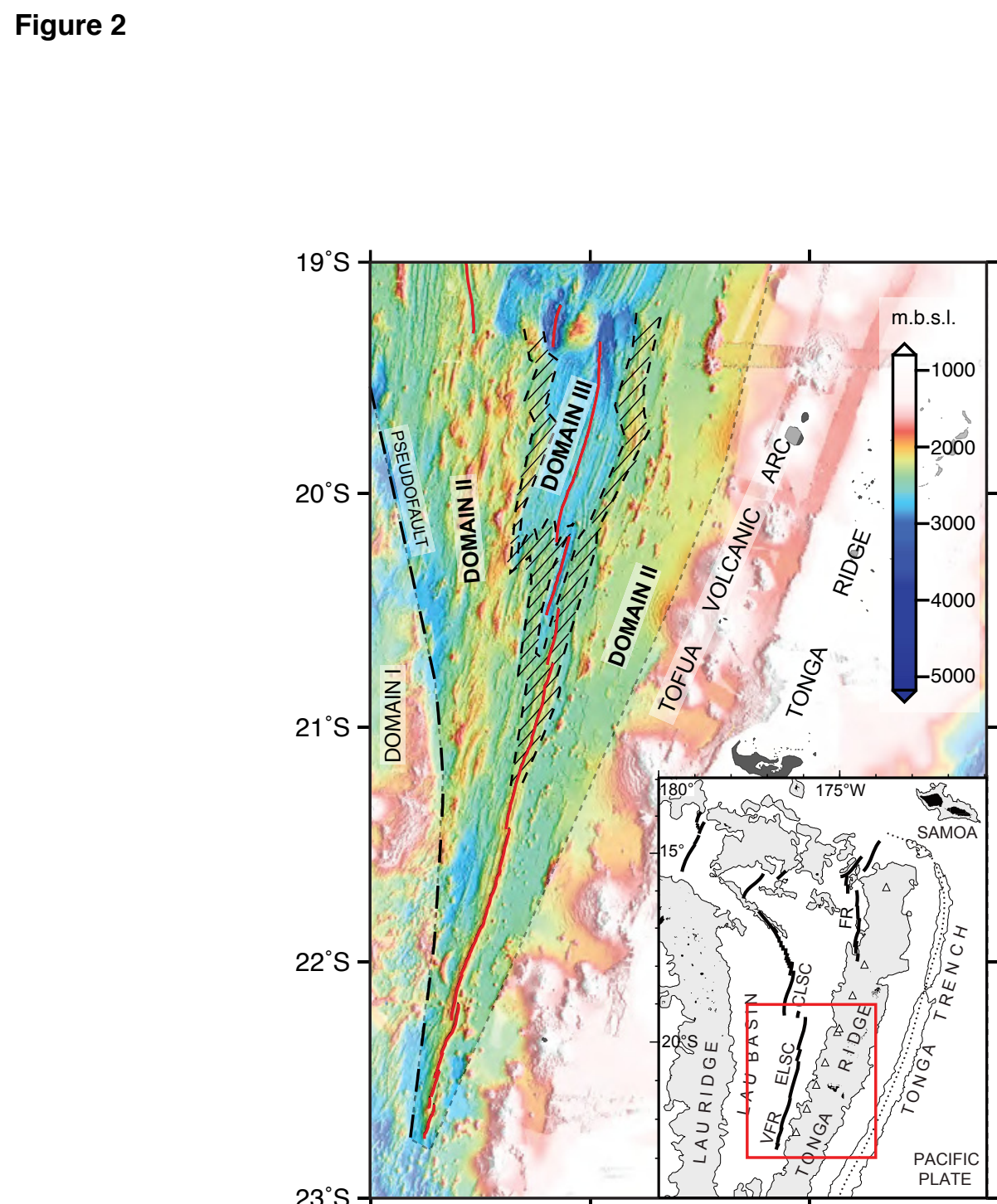

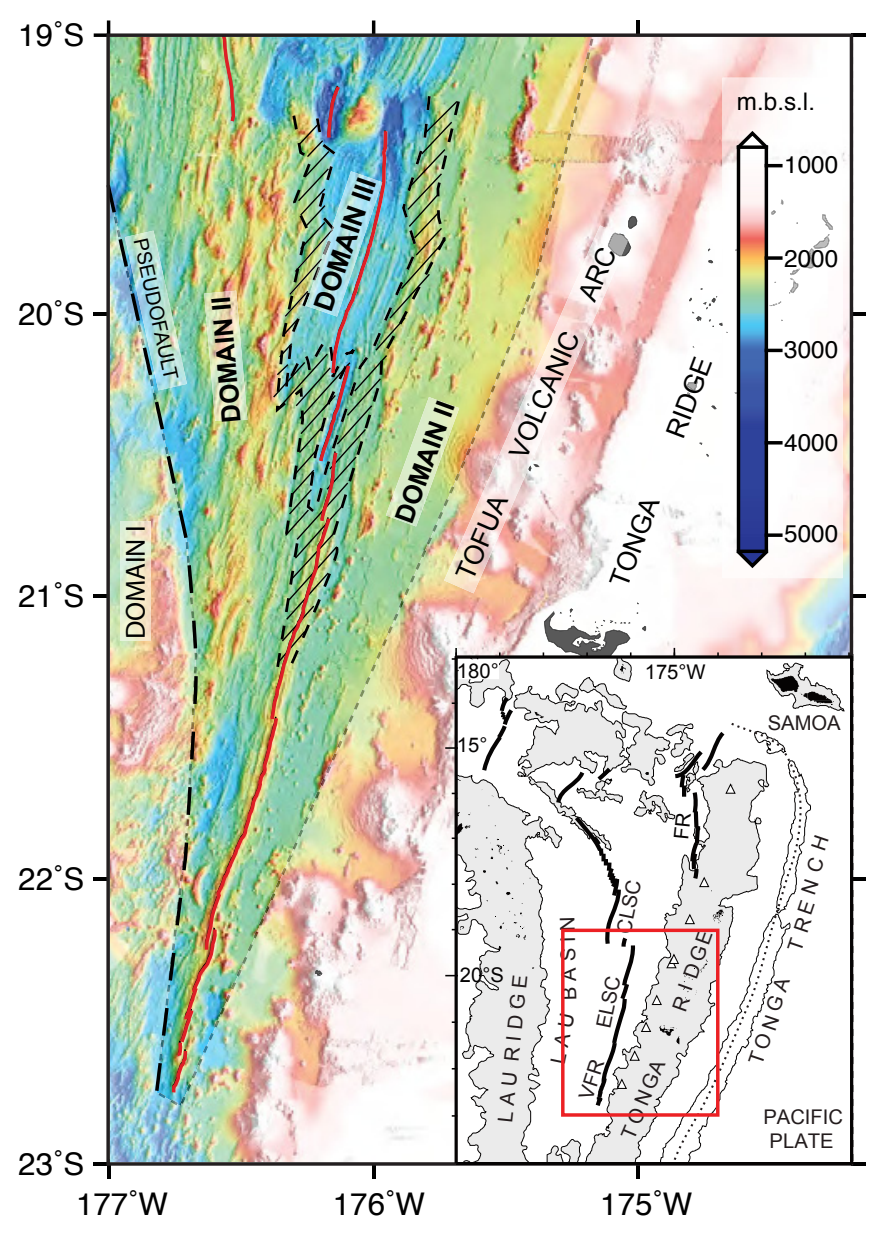

$$
177^{\circ} \mathrm{W} \quad 176^{\circ} \mathrm{W} \quad 175^{\circ} \mathrm{W}
$$




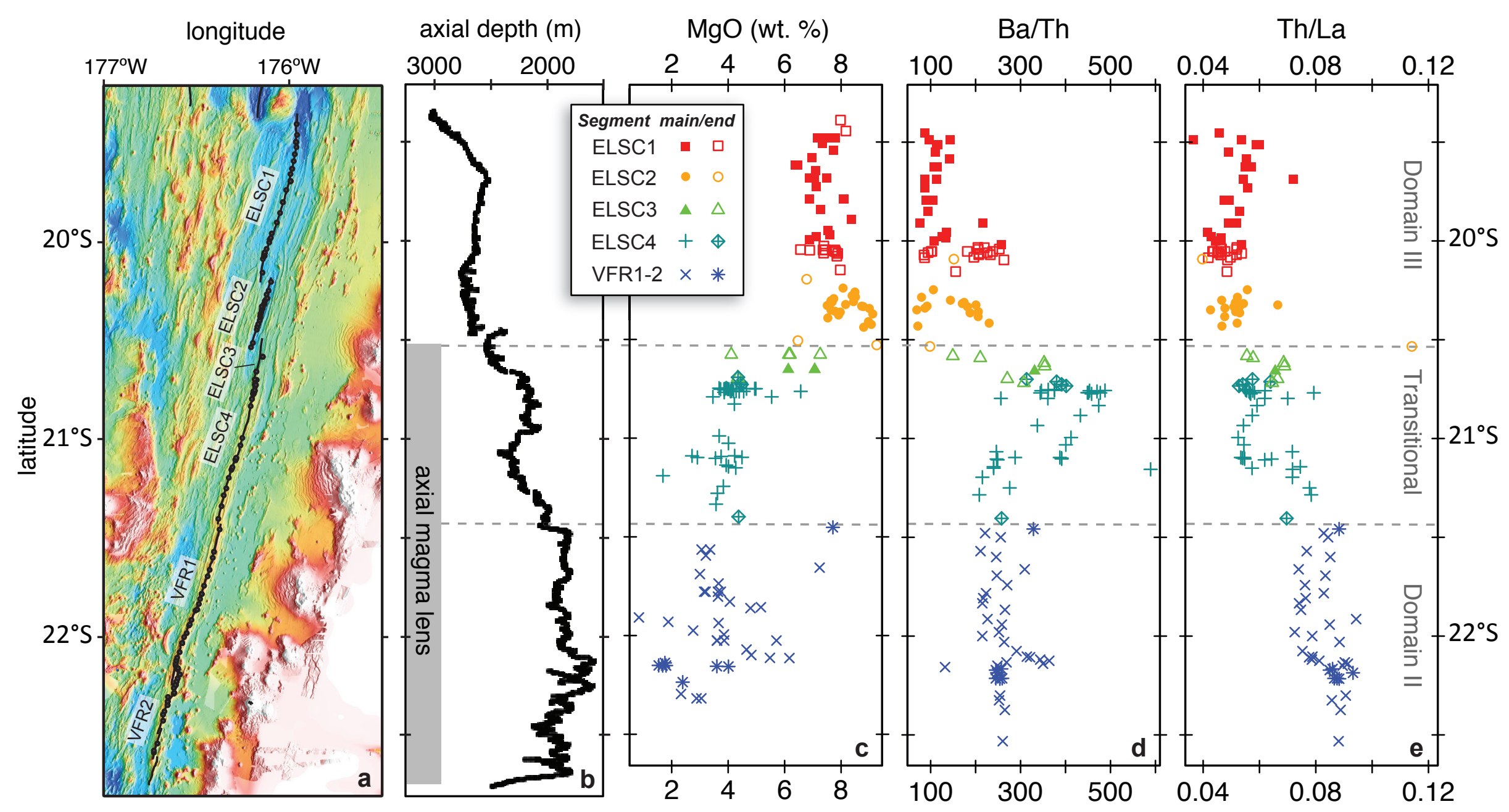



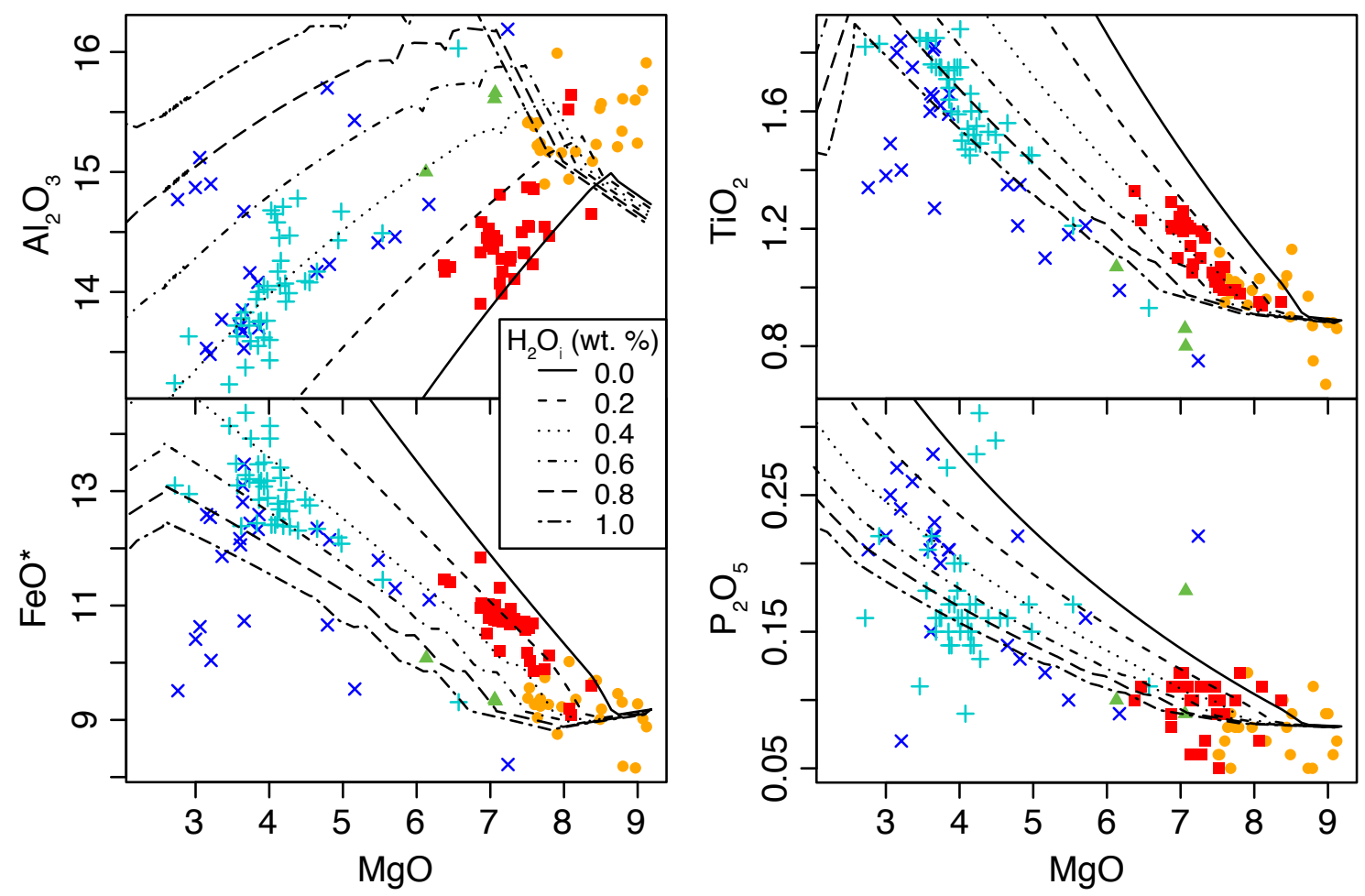

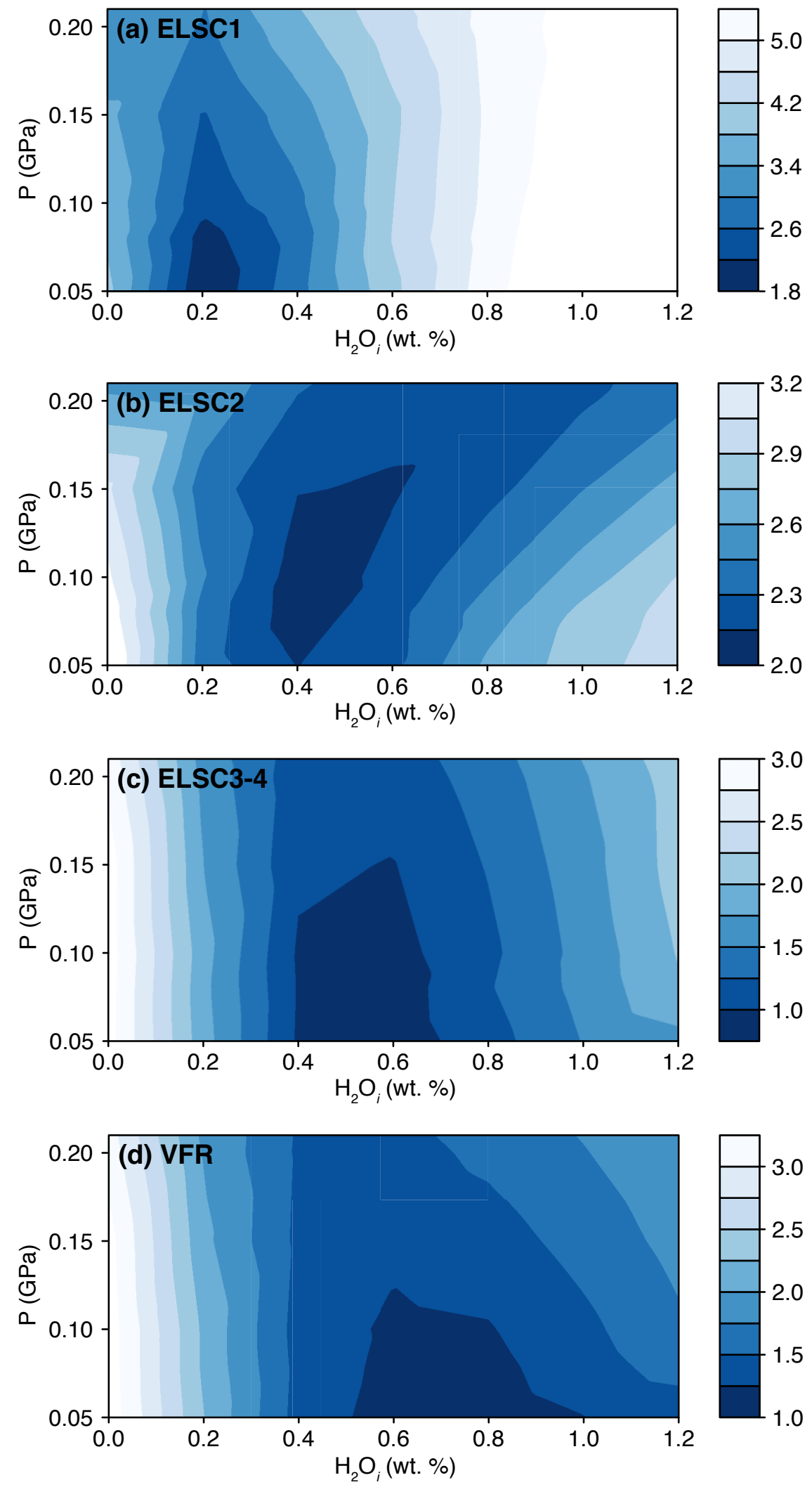

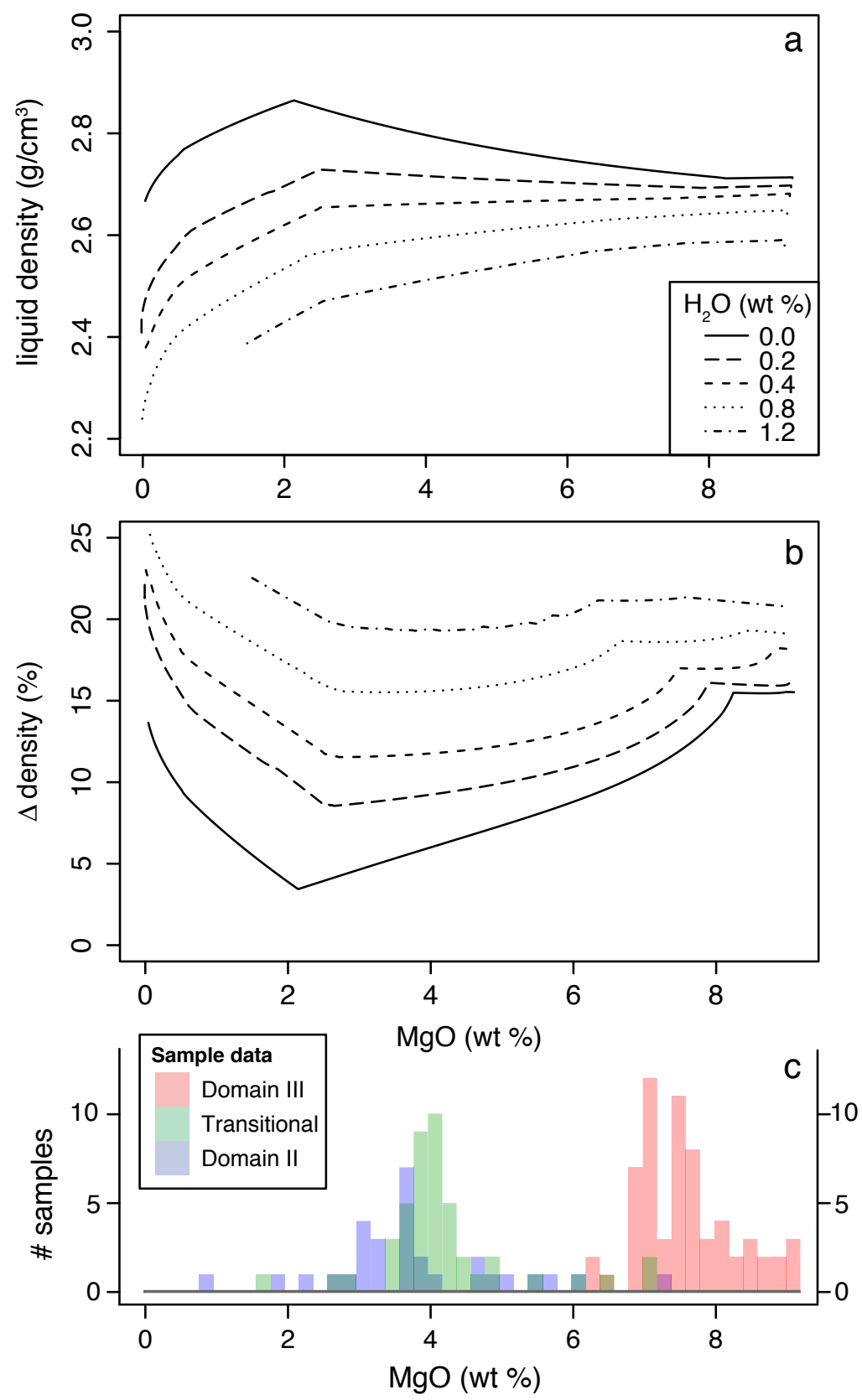